
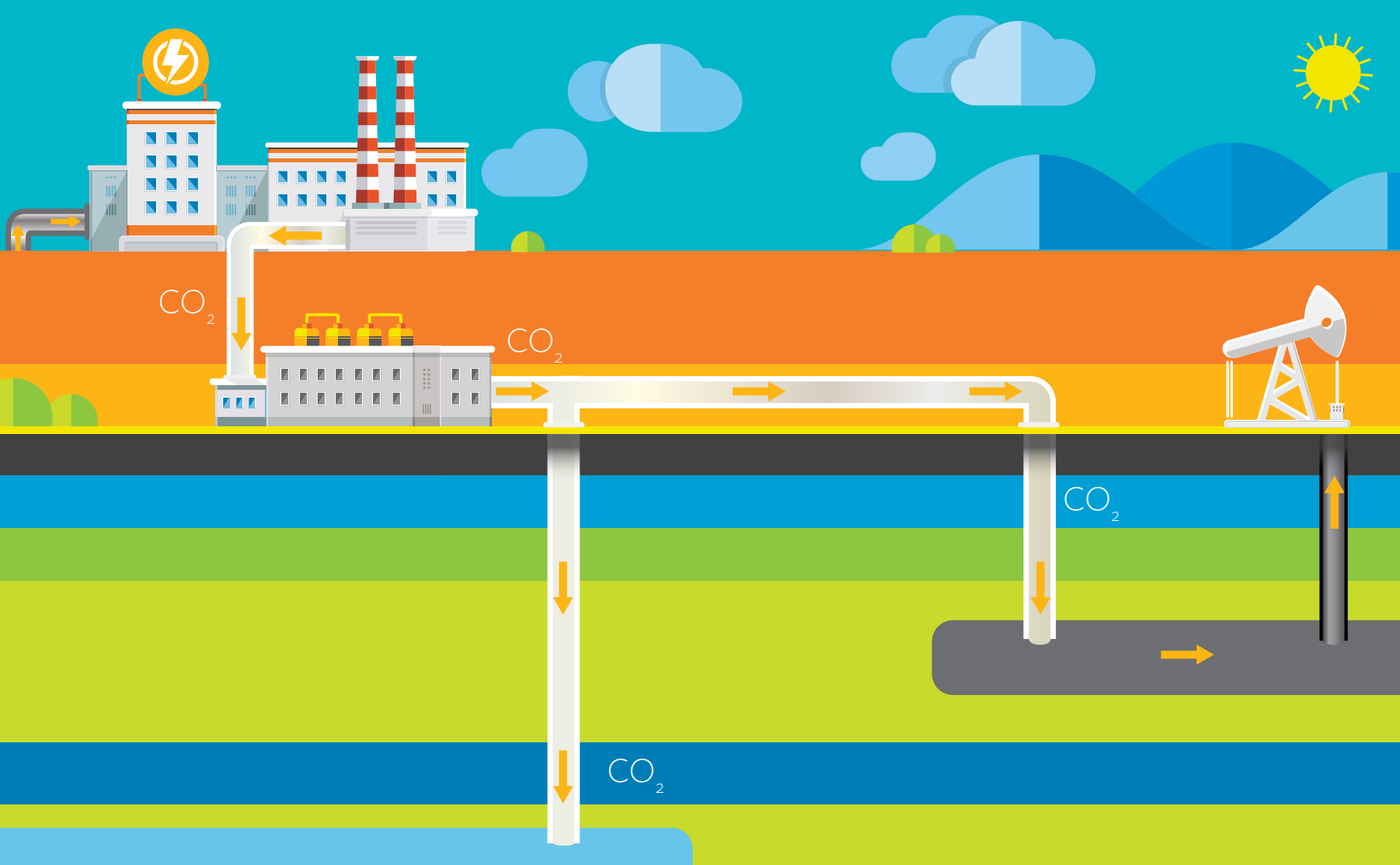

\title{
CARBON DIOXIDE-ENHANCED OIL RECOVERY IN INDONESIA
} AN ASSESSMENT OF ITS ROLE IN A CARBON CAPTURE AND STORAGE PATHWAY

DECEMBER 2019 


\section{CARBON DIOXIDE-ENHANCED OIL RECOVERY IN INDONESIA}

AN ASSESSMENT OF ITS ROLE

IN A CARBON CAPTURE AND STORAGE PATHWAY

DECEMBER 2019 
(C) 2019 Asian Development Bank 6 ADB Avenue, Mandaluyong City, 1550 Metro Manila, Philippines

Tel +632 8632 4444; Fax +63286362444

www.adb.org

Some rights reserved. Published in 2019.

ISBN 978-92-9261-890-2 (print), 978-92-9261-891-9 (electronic)

Publication Stock No. TCS190600

DOI: http://dx.doi.org/10.22617/TCS190600

The views expressed in this publication are those of the authors and do not necessarily reflect the views and policies of the Asian Development Bank (ADB) or its Board of Governors or the governments they represent.

ADB does not guarantee the accuracy of the data included in this publication and accepts no responsibility for any consequence of their use. The mention of specific companies or products of manufacturers does not imply that they are endorsed or recommended by $\mathrm{ADB}$ in preference to others of a similar nature that are not mentioned.

By making any designation of or reference to a particular territory or geographic area, or by using the term "country" in this document, $A D B$ does not intend to make any judgments as to the legal or other status of any territory or area.

This work is available under the Creative Commons Attribution 3.0 IGO license (CC BY 3.0 IGO)

https://creativecommons.org/licenses/by/3.o/igo/. By using the content of this publication, you agree to be bound by the terms of this license. For attribution, translations, adaptations, and permissions, please read the provisions and terms of use at https://www.adb.org/terms-use\#openaccess.

This CC license does not apply to non-ADB copyright materials in this publication. If the material is attributed to another source, please contact the copyright owner or publisher of that source for permission to reproduce it. $\mathrm{ADB}$ cannot be held liable for any claims that arise as a result of your use of the material.

Please contact pubsmarketing@adb.org if you have questions or comments with respect to content, or if you wish to obtain copyright permission for your intended use that does not fall within these terms, or for permission to use the ADB logo.

Corrigenda to ADB publications may be found at http://www.adb.org/publications/corrigenda.

Notes:

In this publication, “\$” refers to United States dollars.

Cover design by Mike Cortez. 


\section{CONTENTS}

Tables, Figures, Boxes, and Maps

Acknowledgments

Abbreviations

Weights and Measures

vii

\section{Executive Summary}

viii

$\begin{array}{ll}\text { I. Introduction } & 1\end{array}$

II. The Technology 2

A. Carbon Capture, Utilization, and Storage to Mitigate Climate Change 2

B. Carbon Dioxide-Enhanced Oil Recovery for Producing Oil 3

C. Carbon Dioxide-Enhanced Oil Recovery as a Means of Storing Carbon 7

D. Global Status and Prospects for Carbon Dioxide-Enhanced Oil Recovery 11

III. Climate Policy in Indonesia $\quad 16$

A. Trends in Energy Use and Greenhouse Gas Emissions $\quad 16$

B. National Climate Mitigation Policy 18

C. Role of Carbon Capture, Utilization, and Storage in Indonesia's Climate Strategy 20

IV. Potential for Carbon Dioxide-Enhanced Oil Recovery in Indonesia 22

A. Potential for Enhancing Crude Oil Production $\quad 22$

B. Availability of Anthropogenic Carbon Dioxide $\quad 24$

C. Candidate Oilfields for Carbon Dioxide-Enhanced Oil Recovery Projects 26

V. Next Steps 33

A. Pilot Studies and Demonstration Projects $\quad 33$

$\begin{array}{ll}\text { B. Addressing Regulatory Barriers } & 35\end{array}$

$\begin{array}{ll}\text { C. Financial Incentives } & 38\end{array}$

$\begin{array}{ll}\text { D. Developing In-Country Capability } & 39\end{array}$

$\begin{array}{ll}\text { References } & 41\end{array}$ 


\section{TABLES, FIGURES, BOXES, AND MAPS}

\section{Tables}

1 Large-Scale Commercial Carbon Dioxide Capture Projects for Carbon Dioxide-Enhanced Oil Recovery

2 Indicators of Economic Development and Energy Use in Indonesia 16

3 Anthropogenic Sources of Carbon Dioxide in Indonesia

4 Pairing of Carbon Dioxide Sources and Candidate Oilfields for Carbon

Dioxide-Enhanced Oil Recovery in Indonesia

5 Evaluation of Carbon Dioxide-Enhanced Oil Recovery Potential at Oilfields in the Kutei Basin in East Kalimatan, Indonesia

\section{Figures}

1 Oil Recovery Techniques 3

2 Illustration of Carbon Dioxide-Enhanced Oil Recovery 5

3 Number of Enhanced Oil Recovery Projects Worldwide by Type 6

$4 \quad$ World Oil Production from Enhanced Oil Recovery by Type in the International Energy Agency's New Policies Scenario 15

5 Historic Trends in Total Primary Energy Supply by Source in Indonesia 17

6 Projected Total Primary Energy Demand by Source in Indonesia 18

7 Remaining Proven Oil Reserves and Production in Indonesia 23

8 Roadmap for the Development of Carbon Capture, Utilization, and Storage in Southeast Asian Countries

\section{Boxes}

1 Oil Recovery Techniques

2 How Big Are the Carbon Dioxide Emissions Reductions from Carbon Dioxide-Enhanced Oil Recovery?

3 The International Energy Agency Greenhouse Gas Research and Development Program's Weyburn-Midale Carbon Dioxide Monitoring and Storage Pilot Project 12

4 Indonesia's Center of Excellence for Carbon Capture and Storage and/or Carbon Capture, Utilization, and Storage

5 The United States 45Q Tax Credit Mechanism for Carbon Capture,

Utilization, and Storage

\section{Maps}

1 Large Anthropogenic Sources of Carbon Dioxide in Indonesia

2 Carbon Dioxide Storage Capacity of the South Sumatra and the East Kalimantan Basins in Indonesia

3 Location of Sukowati and Jambaran-Tiung-Biru Carbon Dioxide-Enhanced Oil Recovery Pilot Project 


\section{ACKNOWLEDGMENTS}

\footnotetext{
This report was prepared under the technical assistance (TA) project Carbon Capture and Storage in the Natural Gas Processing Sector (TA 9189-INO) under the guidance of Shannon Cowlin, senior energy specialist and team lead, Energy Division (SEEN), Southeast Asia Department, Asian Development Bank (ADB). The TA was funded by the Carbon Capture and Storage Fund under the Clean Energy Financing Partnership Facility; financing partners for this fund are the Global Carbon Capture and Storage Institute and the Government of the United Kingdom.
}

The main author of the report is Trevor Morgan, with inputs from Srikanta Mishra, Manoj Valluri, Jared Walker, Lydia Cumming, and Neeraj Gupta of Battelle; M. Rachmat Sule, Wawan Gunawan A. Kadir, Djoko Santoso, Benyamin Sapiie, Dwiharso Nugroho, W. Probo Ananto, Falza I. Wihdany, Oddy A. Mudatzir, Eddy A. Subroto, Eko Widianto, Very Susanto, Sonny Winardhi, Suhada, Riskiray Ryannugroho, Ekkal Dinanto, Alfian, Fatkhan, Tutuka Ariadji, Prasandi A. Aziz, Andri Leits, Bonar Marbun, Antonius Indarto, C. B. Rasrendra, Sanggono Adisasmito, Anggit Raksajati, Sardenianto, Judistira, Eldo P. Putra, Retno G. Dewi, Utjok W. R. Siagian, Yohanes Nuwara, Kevyn A. Gunawan, Michael A. Santoso, Farah Mulyasari and Ilham Dani of ITB; and Usman Pasarai, Oki Hendriana, Yohanes B. Doi Wangge, Dadan Damayandri, Wanda Ali Akbar dan Heru Prasetyo of LEMIGAS.

Florian Kitt, energy specialist, SEEN, and Ridwan Kruniawan, project coordinating consultant, made valuable contributions during the drafting and finalization of the report. Geraldine Reside, project analyst, SEEN; Diane Carabeo, operations assistant, SEEN; Ridwan Kurniawan, project coordinating consultant; and Widhyawan Prawiraatmaja, senior advisor (consultant) provided support through the preparation and publishing of this report. In the energy sector group, Yongping Zhai, the group chief, Toru Ito, senior energy specialist; G. Jinmiao Xu, energy specialist; and Darshak Mehta, consultant, provided useful feedback during the finalization of the report.

The team would like to thank Andrew Jeffries, director, SEEN, and Winfried Wicklein, country director, Indonesia Resident Mission, for support and guidance in the formulation and finalization of the report. The team thanks Andi Bachtiar, vice president of enhanced oil recovery, PT Pertamina EP, for sharing insights and feedback during the report's preparation. The team also thanks Adhi Wibowo, director of oil and gas technology and environment, Directorate General of Oil and Gas, Ministry of Energy and Mineral Resources, and his team, including Putu Suardana, Sendah Hurmuzan Kanam, Mohammad Fahrur Rozi, and Jauhar Fuadi for their inputs and feedback throughout the process. 


\section{ABBREVIATIONS}

$\begin{array}{ll}\text { ADB } & \text { Asian Development Bank } \\ \text { BECCS } & \text { Bioenergy with CCS } \\ \text { CCS } & \text { carbon capture and storage } \\ \text { CCUS } & \text { carbon capture, utilization, and storage } \\ \mathrm{CO}_{2} & \text { carbon dioxide } \\ \text { CoE } & \begin{array}{l}\text { Center of Excellence for carbon capture and storage and/or carbon } \\ \text { capture, utilization, and storage, within the Ministry of Energy and Mineral }\end{array} \\ & \text { Resources of Indonesia } \\ \text { PRC } & \text { People's Republic of China } \\ \text { EOR } & \text { enhanced oil recovery } \\ \text { GHG } & \text { greenhouse gas } \\ \text { IEA } & \text { International Energy Agency } \\ \text { ITB } & \text { Institut Teknologi Bandung (Bandung Institute of Technology) } \\ \text { LEMIGAS } & \text { Lembaga Minyak dan Gas Bumi (Indonesian Research and Development } \\ & \text { Centre for Oil and Gas Technology) } \\ \text { MEMRI } & \text { Ministry of Energy and Mineral Resources of the Republic of Indonesia } \\ \text { MMP } & \text { minimum miscibility pressure } \\ \text { MRV } & \text { measurement, reporting, and verification } \\ \text { NDC } & \text { nationally determined contribution }\end{array}$




\section{WEIGHTS AND MEASURES}

$\begin{array}{ll}\mathrm{b} / \mathrm{d} & \text { barrel per day } \\ \mathrm{Gt} & \text { gigaton } \\ \mathrm{km} & \text { kilometer } \\ \mathrm{Mb} / \mathrm{d} & \text { million barrels of oil per day } \\ \mathrm{Mboe} / \mathrm{d} & \text { million barrels of oil equivalent per day } \\ \mathrm{mmscf} / \mathrm{d} & \text { million standard cubic feet per day } \\ \mathrm{Mt} & \text { metric ton } \\ \mathrm{MMT} & \text { million metric ton } \\ \text { TWh } & \text { terawatt hour }\end{array}$




\section{EXECUTIVE SUMMARY}

Enhanced oil recovery through the injection of carbon dioxide $\left(\mathrm{CO}_{2}-\mathrm{EOR}\right)$ is a proven technology for rejuvenating the production of oil at mature oilfields but can also provide a means of permanently storing carbon dioxide $\left(\mathrm{CO}_{2}\right)$ as much of the gas injected remains incidentally trapped in the field. The use of the technology to mitigate climate change-referred to here as $\mathrm{CO}_{2}$-EOR+-is attracting interest around the world. As a type of carbon capture, utilization, and storage (CCUS) technology, it could make an important contribution to efforts in Indonesia and elsewhere to curb emissions of $\mathrm{CO}_{2}-$ the leading greenhouse gas (GHG) - over the long term and to mitigate climate change. It is widely seen as a stepping stone to other types of carbon capture and storage (CCS) that do not necessarily involve any use of $\mathrm{CO}_{2}$.

At a minimum, $\mathrm{CO}_{2}-\mathrm{EOR}+$ requires the $\mathrm{CO}_{2}$ to come from an anthropogenic source, such as a power station or a natural gas processing plant (since gas extracted from a reservoir often contains significant amounts of $\left.\mathrm{CO}_{2}\right) \cdot \mathrm{CO}_{2}$-EOR always results in some $\mathrm{CO}_{2}$ being stored permanently in the field, even if operated in such a way as to maximize oil production without regard to how much $\mathrm{CO}_{2}$ is stored. But for use of the technology to qualify as a genuine climate mitigation measure, several additional activities need to be undertaken before, during, and following $\mathrm{CO}_{2}$ injection, including additional measurement, reporting, and verification activities. For oilfield operators to opt for anthropogenic sources of $\mathrm{CO}_{2}$ and to choose to maximize storage of that gas at all stages of the project cycle, they either need to be given a financial incentive, such as a carbon tax or price, or to be required to do so through regulation.

The use of $\mathrm{CO}_{2}$-EOR remains relatively limited for now, but is growing rapidly, both in the United States (US), where it was first developed, and in some other countries. And $\mathrm{CO}_{2}-\mathrm{EOR}+$ is starting to take off as new projects are designed with the dual goal of boosting oil production and storing the $\mathrm{CO}_{2}$, usually in response to financial incentives. There are currently 14 large-scale $\mathrm{CO}_{2}$-EOR+ projects in operation around the world with a total injection capacity of around 35 million metric tons (MMT) per year. Ten of them are located in North America, of which eight are in the US; the largest in the world is at the Lula and/or Sapinhoa offshore oilfield in Brazil.

$\mathrm{CO}_{2}$-EOR+ is a potentially attractive win-win solution for Indonesia, by slowing or halting the decline in oil production while addressing the urgent need to curb the country's rapidly rising $\mathrm{CO}_{2}$ emissions. Indonesia is a long-standing producer of crude oil, though production has fallen steadily for more than 20 years. There may be extensive opportunities for enhanced oil recovery (EOR), including using $\mathrm{CO}_{2}$, given the maturity 
of many of the country's oilfields. The only type of EOR that has been deployed so far in the country on a commercial scale is steam flooding. At the same time, energy use and GHG emissions in Indonesia are expected to continue to grow briskly in response to economic and population growth and continuing heavy reliance on coal and other fossil fuels. Under its nationally determined contribution to the United Nations Framework Convention on Climate Change, the Government of Indonesia is committed to reducing national emissions of $\mathrm{CO}_{2}$ and other $\mathrm{GHG}$ by $29 \%$ below a baseline trend by 2030 unconditionally and by up to $41 \%$ on the condition that international support for finance, technology transfer, and capacity building is made available.

The main potential sources of anthropogenic $\mathrm{CO}_{2}$ in Indonesia are natural gas and associated oil and gas processing plants, and industrial processes that involve the conversion of hydrocarbons. Power stations and petrochemical plants, including fertilizer factories, could also capture and supply $\mathrm{CO}_{2}$ for $\mathrm{CO}_{2}-\mathrm{EOR}+$. The processing of natural gas is likely to be the cheapest source of high-purity $\mathrm{CO}_{2}$ now and in the future. The $\mathrm{CO}_{2}$ has to be removed (along with other impurities) before the natural gas can be distributed and consumed, so that the only additional cost is transporting it to the oilfield for injection. The availability of $\mathrm{CO}_{2}$ from gas processing is likely to grow as several of the gas fields that are expected to come on stream in the coming years have particularly high $\mathrm{CO}_{2}$ content.

A number of studies have already been carried out to assess the potential for $\mathrm{CO}_{2}-\mathrm{EOR}+$ in Indonesia and to match sources of $\mathrm{CO}_{2}$ with oilfields. The large amount of oil remaining in most of Indonesia's mature oilfields suggests that there is significant technical potential, though the economic potential is likely to be far smaller, especially at low oil prices. The cost of procuring the $\mathrm{CO}_{2}$ is particularly important to the economic viability of deploying the technology. The most promising candidates for $\mathrm{CO}_{2}$-EOR+ projects are mature fields with declining production that are located in close vicinity to low-cost sources of $\mathrm{CO}_{2}$, such as natural gas processing plants.

The critical first step in the process of developing $\mathrm{CO}_{2}-\mathrm{EOR}+$ in Indonesia is to launch an initial pilot project. Commercial projects will only follow if at least one pilot and demonstration project has been operating successfully for several years. The learning and experiences from pilot and demonstration projects will be of enormous value in helping operators design commercial projects and helping policy makers draw up an effective legal and regulatory framework.

A pilot project at the Sukowati oilfield located in East Java has been proposed. The project consists of four production wells and $\mathrm{C} \mathrm{C}_{2}$ injection well. If the pilot proves to be successful, a commercial-scale project using a miscible process is envisaged, involving the use of all 35 existing production wells and drilling new $\mathrm{CO}_{2}$ and water injection wells. The $\mathrm{CO}_{2}$ needed for the pilot project would be sourced from the Sukowati field itself. (The gas currently produced from the field contains about $\left.40 \% \mathrm{CO}_{2}\right)$. 


\section{Since $\mathrm{CO}_{2}$-EOR+ is a new activity in Indonesia, it requires the development of a} comprehensive legal and regulatory framework. A draft presidential decree setting out a general framework for CCS was completed in March 2019-the first of its kind in a developing country-building on existing regulations governing the upstream sector and industrial activities. The primary objective of the decree is to establish a performance-based system of permitting for the storage of $\mathrm{CO}_{2}$. It sets out the standards by which CCS projects shall be permitted with the objective of mitigating associated risks, covering both pilot and full commercial CCS projects. The decree exempts pilot projects involving the injection of less than 150,000 tons of $\mathrm{CO}_{2}$ from certain requirements and allows the regulator to waive other requirements on a caseby-case basis. The development of a more comprehensive framework at a later stage is expected to benefit from the lessons learned from the pilot projects.

There is also a need to review and recommend specific policies and tax incentives for $\mathrm{CO}_{2}-\mathrm{EOR}+$ in Indonesia. For large-scale commercial projects to take off, a significant financial incentive in the form of a carbon price or tax credit will probably be necessary, especially if oil prices fall. The development of human capital will also be an important element in achieving the successful demonstration and subsequent large-scale deployment of $\mathrm{CO}_{2}-\mathrm{EOR}+$ technology in Indonesia. 


\title{
I. INTRODUCTION
}

\begin{abstract}
The Asian Development Bank (ADB) provided technical assistance to the Republic of Indonesia under the program entitled Pilot Carbon Capture and Storage Activity in the Natural Gas Processing Sector. ${ }^{1}$ Carbon capture and storage (CCS) is a suite of emerging technologies that involves sequestering carbon dioxide $\left(\mathrm{CO}_{2}\right)$ - the leading greenhouse gas (GHG) - from fossil-fuel combustion or industrial processes and storing it permanently underground. It is widely regarded as a potentially important means of reducing anthropogenic emissions of $\mathrm{CO}_{2}$, alongside a shift in energy use to less carbon-intensive sources, improvements in $\mathrm{CO}_{2}$ efficiency, and energy conservation. A large reduction in worldwide emissions is urgently required to meet the internationally agreed goal of limiting the rise in global temperatures to below $2^{\circ} \mathrm{C}$ under the Paris Agreement on climate change. ADB seeks to facilitate the inclusion of CCS in national low-carbon growth strategies and polices, and its eventual deployment in its member countries.
\end{abstract}

The purpose of this report is to provide a broad initial assessment of the potential for $\mathrm{CO}_{2}$-enhanced oil recovery (EOR) to be deployed in Indonesia as a form of CCS, thereby contributing to the country's climate policy objectives. $\mathrm{CO}_{2}$-EOR is an established technology for boosting the recovery of oil at mature oilfields through the injection of $\mathrm{CO}_{2}$, but it also provides a means of storing $\mathrm{CO}_{2}$ since much of the gas injected remains permanently trapped in the field. $\mathrm{CO}_{2}$-EOR used with the aim of storing $\mathrm{CO}_{2}$ from anthropogenic sources (referred to in this report as $\mathrm{CO}_{2}-\mathrm{EOR}+$ ) is a type of carbon capture, utilization, and storage (CCUS) technology, itself a variant of CCS (pure CCS does not involve any use of the $\mathrm{CO}_{2}$ ). It is expected that $\mathrm{CO}_{2}$-EOR+ will continue to play a major role in supporting the initial deployment of CCUS in the United States (US), where it is already well established, and elsewhere. ${ }^{2} \mathrm{CO}_{2}-\mathrm{EOR}+$ is widely seen as a stepping stone to other types of CCS.

This assessment evaluates the relevance of $\mathrm{CO}_{2}-\mathrm{EOR}+$ as a climate mitigation strategy in Indonesia, which would most likely be based initially on $\mathrm{CO}_{2}$ captured during the processing of natural gas produced from onshore oil and gas fields. A successful pilot project will be critical to providing the data and experience needed to deploy $\mathrm{CO}_{2}-\mathrm{EOR}+$ and other types of CCS projects on a large scale in the country. The report is also intended to inform all potential stakeholders in CCS and climate policymaking generally in Indonesia and further afield of the opportunities and challenges that lie ahead.

\footnotetext{
ADB. Indonesia: Pilot Carbon Capture and Storage Activity in the Natural Gas Processing Sector (TA 9189-INO). https://www.adb.org/projects/49204-002/main.

2 International Energy Agency. Carbon Capture, Utilisation and Storage. https://www.iea.org/topics/carbon-capture-andstorage/.
} 


\section{THE TECHNOLOGY}

\section{A. Carbon Capture, Utilization, and Storage to Mitigate Climate Change}

CCUS involves the capture of $\mathrm{CO}_{2}$ from fuel combustion or industrial processes, its transportation by ship or pipeline, its use as a resource to create valuable products or services, and its permanent storage deep underground in geological formations. CCUS is generally categorized as a type of CCS-a suite of technologies that prevent $\mathrm{CO}_{2}$ emissions from entering the atmosphere, while pure CCS does not involve any utilization of the $\mathrm{CO}_{2}$. The overall cost of CCS can be substantially reduced when the $\mathrm{CO}_{2}$ is used for an industrial purpose, such as EOR, before being permanently stored.

CCUS technologies can also provide a means of removing $\mathrm{CO}_{2}$ from the atmosphere, i.e., "negative emissions," to offset emissions from sectors where direct abatement is not economically or technically feasible, such as in aviation transport or agriculture (International Energy Agency, 2017). Limiting the increase in global temperature to $1.5^{\circ} \mathrm{C}$-the ambition set out in the Paris Agreement-would probably require the eventual deployment of technologies to actually remove carbon from the atmosphere in addition to nearer term actions to completely phase out emissions of GHGs. Bioenergy with CCS, also known as BECCS, is the most promising negative emissions technology. BECCS involves the conversion of biomass, which extracts $\mathrm{CO}_{2}$ from the atmosphere as it grows, to chemical products or other forms of energy with the resulting $\mathrm{CO}_{2}$ captured and geologically stored. Possible applications of BECCS include power generation, combined heat and power, pulp and paper mills, lime kilns, ethanol plants, biogas refineries, and biomass gasification plants (footnote 2 ).

Although it is not yet widely deployed, CCUS is expected to play an important role in meeting energy and climate goals worldwide in the coming decades. It is seen as the only option to reduce $\mathrm{CO}_{2}$ emissions to a near-zero level from fossil power plants and other large point sources, such as gas processing plants. In the sustainable development scenario of the latest World Energy Outlook of the International Energy Agency (IEA), in which emissions follow a trajectory consistent with the Paris Agreement limiting the increase in global temperature to less than $2^{\circ} \mathrm{C}$, CCUS accounts for $16 \%$ of the reduction in emissions needed globally in 2040 compared with current levels (International Energy Agency, 2018a). This would require a rapid expansion in the deployment of CCUS, from around 30 million metric tons (MMT) of $\mathrm{CO}_{2}$ captured per year at present to around 2,300 MMT per year by 2040. 
CCUS can also contribute to broader energy security and environmental, societal, and economic goals by:

(i) enabling greater energy diversity, including the continuing, cleaner use of fossil fuels;

(ii) maintaining long-term employment and investment opportunities in energyintensive industries;

(iii) protecting the value of substantial investments in energy and other industrial infrastructure that have already been made;

(iv) expanding the choice of technologies for power generation; and

(v) enabling investment in alternative energy sources and carriers, including lowemission hydrogen production from fossil fuels.

\section{B. Carbon Dioxide-Enhanced Oil Recovery for Producing Oil}

$\mathrm{CO}_{2}$-EOR, involving the injection of $\mathrm{CO}_{2}$ into oil reservoirs to enhance oil recovery, has been practiced on a commercial scale since 1972, when several natural gas processing plants in the Val Verde area of West Texas began capturing $\mathrm{CO}_{2}$ to supply EOR operations at nearby mature oilfields. It is the leading type of tertiary oil recovery technique currently in use in the US and worldwide (Figure 1 and Box 1).

Figure 1: Oil Recovery Techniques

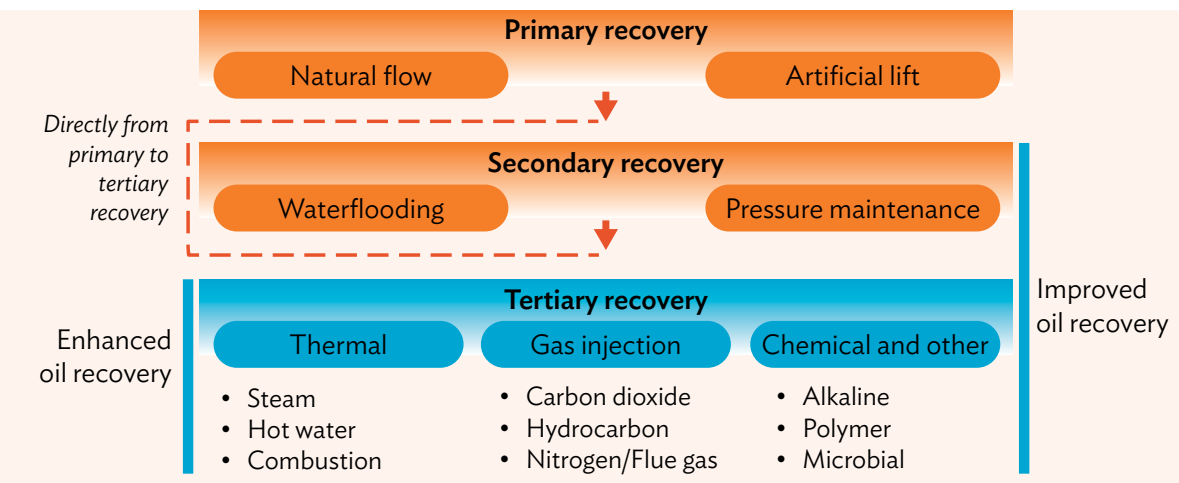

Source: G. Kristopher. 2015. Why it's Important to Know the Crude Oil Extraction Process. Market Realist. 15 January. https://marketrealist.com/2015/01/important-know-crude-oil-extractionprocess/.

The limited deployment of $\mathrm{CO}_{2}$-EOR technology to date reflects various technical and economic constraints. The main factors that determine its feasibility in practice are the geological and petrophysical characteristics of a given reservoir; the physical and chemical characteristics of the oil; the production history, condition, and accessibility of the field; and the availability and cost of $\mathrm{CO}_{2}$. $\mathrm{CO}_{2}$-EOR usually involves a miscible process, i.e., mixing of $\mathrm{CO}_{2}$ with the oil to improve the rate of flow of the oil to the wellbore. As with other EOR techniques, it is usually effective only for light crude oils held in carbonate and sandstone formations. In some cases, another 


\section{Box 1: Oil Recovery Techniques}

Conventional oilfields typically have three main production phases. In the first phase, oil typically flows unaided to the well under the pressure that exists naturally within the reservoir, but the rate of flow tends to decline over time as extraction of the oil (and water) progressively leads to a decline in pressure. At this point, producers may apply a range of secondary and tertiary techniques to enhance oil recovery and compensate for declining production. Secondary recovery involves the injection of fluids, usually water, into the well to increase pressure and flow rates. Once extracted, the oil and water are easily separated as they are not miscible, i.e., they do not mix. In practice, secondary recovery is often applied at an early stage in the production lifetime of an oilfield, especially if the natural pressure of the reservoir is low.

Tertiary recovery-the third level of production enhancement, commonly referred to as enhanced oil recovery (EOR) -involves the use of techniques that aim to change the properties of the oil or the reservoir rock, or alter flow patterns within the reservoir, to make the oil flow more easily to the well, as well as increase reservoir pressure. This requires injecting into the reservoir a substance that will interact with oil to alter its density or viscosity, reduce the adhesiveness of the rock to the oil ("wettability") or plug high-permeability flow paths in the reservoir. ${ }^{a}$ Tertiary methods include thermal recovery (which usually involves injecting steam or hot water into the field), chemical flooding (the injection of a chemical or mixture of chemicals such as alkaline ones or polymers), and the injection of a miscible gas, such as carbon dioxide $\left(\mathrm{CO}_{2}\right)$. The choice of recovery technique in each case depends on the characteristics of the reservoir, the degree of depletion, and economic considerations. Gas injection, mainly involving $\mathrm{CO}_{2}$, accounts for nearly $60 \%$ of EOR production in the United States. ${ }^{b}$ Experience there shows that $\mathrm{CO}_{2}$-EOR can boost recovery by $5 \%$ to $15 \%$ of the original oil in place, depending on the miscibility of oil and $\mathrm{CO}_{2} \cdot{ }^{c}$

a International Energy Agency (IEA). 2015. Storing $\mathrm{CO}_{2}$ through Enhanced Oil Recovery: Combining EOR with $\mathrm{CO}_{2}$ Storage (EOR+) for Profit. Paris: Organisation for Economic Co-operation and Development and IEA.

b Government of the United States, Department of Energy. 2019. Enhanced Oil Recovery. Washington, DC: Office of Fossil Energy. https://www.energy.gov/fe/science-innovation/oil-gas-research/ enhanced-oil-recovery.

c IEA. 2013. Resources to Reserves. Paris: Organisation for Economic Co-operation and Development and IEA.

Source: Authors.

miscible gas, such as nitrogen and hydrocarbon gases (e.g., propane or butane), may be preferred on technical or economic grounds. The oil price is the single most important determinant of the economics of $\mathrm{CO}_{2}$-EOR projects, with a higher price typically leading to more investment in new projects and higher rates of $\mathrm{CO}_{2}$ injection. $\mathrm{CO}_{2}$-EOR is generally a costlier technique than primary or secondary ones.

In a standard miscible $\mathrm{CO}_{2}$-EOR process, relatively pure $\mathrm{CO}_{2}$ (typically at least $95 \%$ by volume) is injected into the reservoir and mixes with the oil (Figure 2). Mixing oil and $\mathrm{CO}_{2}$ has the effect of reducing the capillary forces that trap the oil in the reservoir rock and making it flow more freely to the producing well. Other gases, such as nitrogen and hydrocarbon gases including propane and butane, can also be injected in a similar 
Figure 2: Illustration of Carbon Dioxide-Enhanced Oil Recovery

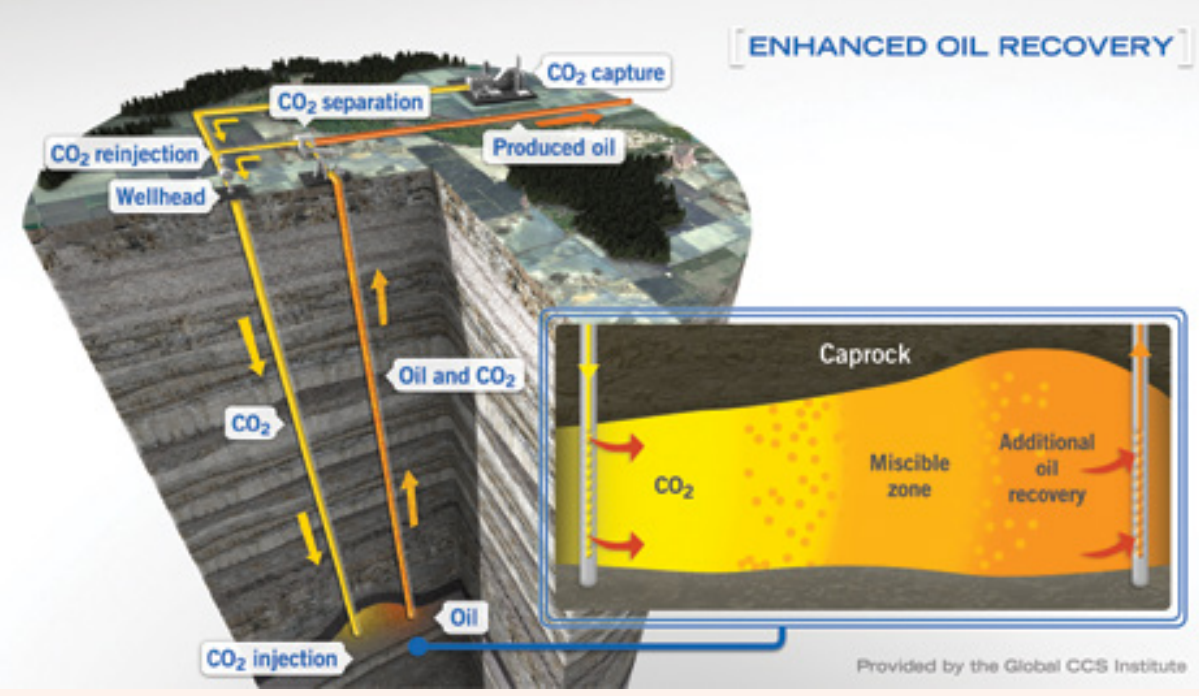

$\mathrm{CO}_{2}=$ carbon dioxide.

Source: Global CCS Institute. CCS Image Library - Carbon Capture and Storage Images. https://www. globalccsinstitute.com/resources/ccs-image-library/ (accessed 14 October 2019).

fashion, but $\mathrm{CO}_{2}$ is often preferred as it mixes with oil at a lower pressure. As a result, $\mathrm{CO}_{2}$-EOR tends to be more effective in relatively shallow reservoirs, where pressure tends to be lower (International Energy Agency, 2015). $\mathrm{CO}_{2}$ may also be cheaper.

In a few cases, $\mathrm{CO}_{2}$ is injected (usually along with water) without any significant mixing with the oil (an immiscible process), typically because the oil is too heavy, to force the oil to the wellbore through pressure in a similar fashion to secondary recovery techniques. Immiscible $\mathrm{CO}_{2}$ injection or flooding (as it is sometimes called) is generally less efficient than miscible injection at producing oil in terms of the ratio of $\mathrm{CO}_{2}$ injected and oil produced.

For miscibility to occur, the pressure in the reservoir has to be above the minimum miscibility pressure (MMP) - the pressure at which $\mathrm{CO}_{2}$ mixes with the oil instead of sweeping it out of the way. The MMP varies according the type of oil and geology but is typically in excess of 1,500 pounds per square inch for light crude oil (Muslim et al., 2013). Injecting in an alternating fashion slugs of $\mathrm{CO}_{2}$ and water produced from the reservoir can also enhance miscibility, as the presence of water channels the movement of $\mathrm{CO}_{2}$ into the tighter parts of the reservoir. This technique, known as "water-alternating-gas," reduces the need for $\mathrm{CO}_{2}$ per barrel of oil recovered and, therefore, the cost of procuring $\mathrm{CO}_{2}$.

When $\mathrm{CO}_{2}$ reaches the production wellhead, it is separated from the produced oil so that it can be reinjected (i.e., recycled) to save on the cost of fresh supplies of the gas. $\mathrm{CO}_{2}$ usually starts to "break through" at production wells relatively soon after the start of injection. Over the life cycle of the EOR project, the $\mathrm{CO}_{2}$ injection and recovery cycles are repeated many times, with smaller amounts of new $\mathrm{CO}_{2}$ added 
in each cycle as less and less of the gas is retained in the rock. Typically, the injection of one ton of $\mathrm{CO}_{2}$ yields between two and three barrels of oil (International Energy Agency, 2009).

In principle, $\mathrm{CO}_{2}$ recycling means that the gas is not released to the atmosphere. Quantitative data on fugitive emissions during handling operations at surface facilities from current $\mathrm{CO}_{2}$-EOR projects are limited but estimates that do exist suggest that such emissions are minimal. For example, losses have been estimated at less than $0.3 \%$ of the total volume of $\mathrm{CO}_{2}$ injected at the Elk Hills $\mathrm{CO}_{2}$-EOR project in the US (Hill, Hovorka, and Melzer, 2013).

The contribution of $\mathrm{CO}_{2}$-EOR to global oil production is relatively small at present but is growing rapidly. In 2017, there were 166 projects in operation around the world, all but 14 of which were in the mid-west US, close to where the technology was first developed and applied. Global output of oil from these projects, almost all of which are onshore, amounted to about 450,000 barrels per day (b/d)-equal to about $0.5 \%$ of world output. ${ }^{3}$ Both the number of projects and output have more than doubled worldwide since the turn of the century (Figure 3).

Figure 3: Number of Enhanced Oil Recovery Projects Worldwide by Type

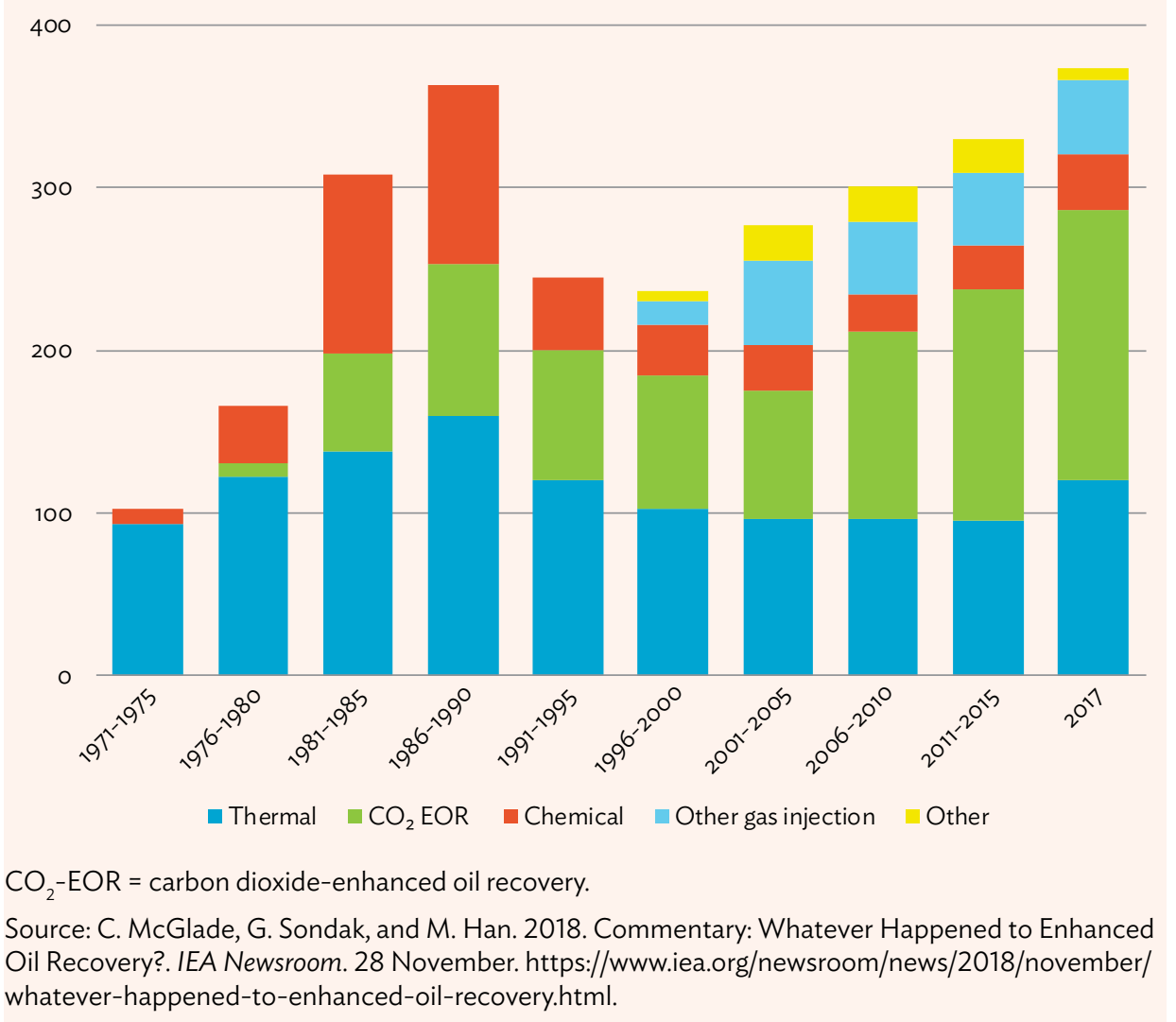

3 International Energy Agency (IEA). 2018. World Energy Outlook 2018 - EOR Database. https://www.iea org/media/publications/weo/EOR-database-WEO18.xlsx Organisation for Economic Cooperation and Development/IEA (accessed 14 October 2019). 
The particular success of the technology in the US is due to several factors, notably the maturity of the industry, a set of geological and petrophysical characteristics that make mature $\mathrm{US}$ fields conducive to $\mathrm{CO}_{2}$ injection, the availability of inexpensive sources of $\mathrm{CO}_{2}$ and an extensive $\mathrm{CO}_{2}$ pipeline system, and a favorable fiscal and legal framework. In 1980, faced with the prospect of declining domestic oil production, the federal government introduced the Crude Oil Windfall Profit Tax, which kick-started the US EOR industry by significantly reducing its tax burden. In 2018, the US tax code section $45 \mathrm{Q}$ tax credit was amended to provide a tax reduction of up to $\$ 35$ per ton of $\mathrm{CO}_{2}$ injected for 12 years and permanently stored in EOR operations on the condition that the gas would otherwise be emitted by an industrial facility or power plant (Section V. Next Steps). ${ }^{4}$

Most $\mathrm{CO}_{2}$ used in US projects today comes from naturally occurring underground reservoirs, though new projects are underway to capture the $\mathrm{CO}_{2}$ emitted from industrial applications such as natural gas processing, fertilizer, ethanol, and hydrogen plants-either in response to policy incentives or because naturally occurring reservoirs of $\mathrm{CO}_{2}$ are not close at hand. In fact, one of the earliest large-scale $\mathrm{CO}_{2}$-EOR projects, at the Weyburn oilfield in Saskatchewan, Canada, which started up in 2000, makes use of anthropogenic $\mathrm{CO}_{2}$ piped in via a 320-kilometer $(\mathrm{km})$ pipeline from a coal-gasification plant in North Dakota in the US. ${ }^{5}$ The project was expanded to include the adjacent Midale field in 2005. ${ }^{6}$ Since 2014, the Boundary Dam power station in Saskatchewan, Canada also supplies $\mathrm{CO}_{2}$ to the Weyburn and Midale fields. The Yanchang CCUS project, under construction in the People's Republic of China (PRC), which is supported by ADB, involves the capture of more than 400,000 tons of $\mathrm{CO}_{2}$ per year from two coal-gasification plants and its use for $\mathrm{CO}_{2}$-EOR at local oil fields.

\section{Carbon Dioxide-Enhanced Oil Recovery as a Means of Storing Carbon}

Although the technology was developed solely with the aim of enhancing oil recovery, the use of $\mathrm{CO}_{2}-\mathrm{EOR}$ as a means of permanently storing the gas in the ground to mitigate climate change-referred to here as $\mathrm{CO}_{2}$-EOR+-is attracting interest around the world. It has the potential to significantly reduce overall $\mathrm{CO}_{2}$ emissions from oil (Box 2). The US Environmental Protection Agency has acknowledged that $\mathrm{CO}_{2}$ can be safely stored when injected through permitted

4 Government of the United States, Office of the Law Revision Counsel. 2019. 26 USC 45Q: Credit for Carbon Oxide Sequestration. Washington, DC: United States Code. 3 October. http://uscode.house.gov/view. xhtml?req=\%28title:26\%20section:45Q\%20edition:prelim\%29 (accessed 14 October 2019).

5 Petroleum Technology Research Centre. Weyburn-Midale: The IEA GHG Weyburn-Midale $\mathrm{CO}_{2} \mathrm{Monitoring}$ and Storage Project. https://ptrc.ca/projects/past-projects/weyburn-midale.

6 According to the IEA, the Weyburn-Midale EOR project produced 17,100 b/d of incremental oil (over and above what would have been produced without $\mathrm{CO}_{2}$ injection) in 2017. Earlier data for 2012 show production of $18,000 \mathrm{~b} / \mathrm{d}$ and an injection rate of around 13,000 tons of $\mathrm{CO}_{2}$ per day, i.e., about 1.5 barrels of oil per ton of $\mathrm{CO}_{2}$. Of this gas, 6,500 tons were purchased and 6,500 tons recycled, or approximately 3 barrels per purchased ton of $\mathrm{CO}_{2}(\mathrm{IEA}, 2 \mathrm{O} 4)$. 


\section{Box 2: How Big Are the Carbon Dioxide Emissions Reductions from Carbon Dioxide-Enhanced Oil Recovery?}

Carbon dioxide-enhanced oil recovery $\left(\mathrm{CO}_{2}\right.$-EOR+) maximizes storage of carbon dioxide $\left(\mathrm{CO}_{2}\right)$, thereby cutting emissions. But it also boosts the production of oil, the majority of which is burned as fuel, resulting in additional emissions. The overall net impact on emissions depends on factors specific to each project and whether the oil produced displaces or supplements oil that would otherwise come from other sources.

At the project level, emissions depend on how much $\mathrm{CO}_{2}$ is stored, the source of the gas, the permanence of the storage, and how much energy is used in the production process. Energy requirements and their associated emissions relative to conventional production can be substantial because of $\mathrm{CO}_{2}$ recycling, which involves separation of the gas from the produced liquids and other gases. ${ }^{a}$ The more $\mathrm{CO}_{2}$ that is permanently stored in the field, the more that is obtained from anthropogenic sources and the less energy that is used in producing the oil, the bigger the emission savings will be compared with a conventional oil project.

The impact of the oil produced from a $\mathrm{CO}_{2}$-EOR+ project on the global oil market also affects $\mathrm{CO}_{2}$ emissions from the use of the oil. If the oil simply replaces that from other projects that do not involve $\mathrm{CO}_{2}$ storage, those emissions will not change. But if that oil adds to global oil supply, oil prices could fall, boosting demand and leading to higher emissions at the point of use, offsetting at least part of the savings at the project level. For $\mathrm{CO}_{2}-\mathrm{EOR}+$ to be attractive to the operator of the field, the cost of recovering a barrel of oil must be lower than that produced from competing options (other types of EOR at the same field or the development of other resources). Other things being equal, this would be expected to lead to a fall in the price of oil relative to what it would be were the investment in the project not to go ahead. The extent to which this would raise demand and emissions depends on the elasticity of demand for oil and how other suppliers, notably members of the Organization of the Petroleum Exporting Countries respond. For $\mathrm{CO}_{2}$-EOR+ to lower net emissions, the amount of $\mathrm{CO}_{2}$ stored would need to exceed the increase in emissions due to lower prices.

In practice, assessing the net impact on emissions requires a quantitative life-cycle assessment, involving modeling of oil market dynamics and taking account of project-specific characteristics. Initial studies that have been carried out suggest that the net emissions savings can be significant. The International Energy Agency (IEA) has calculated that the overall emissions reductions that could be achieved amount to 0.5-1.5 tons of $\mathrm{CO}_{2}$ per ton injected, depending on the configuration of the project and the type of oil displaced. ${ }^{b}$ These estimates are underpinned by an assessment that adding very large amounts of $\mathrm{CO}_{2}$-EOR potential to global oil supply would result in about 0.8 barrels of higher cost oil production being displaced for each barrel produced using $\mathrm{CO}_{2}$-EOR and 0.2 barrels of additional oil. In all cases, the $\mathrm{CO}_{2}$ is assumed to come from anthropogenic sources.

Another study using data for the United States (US) industry shows that life-cycle emissions from $\mathrm{CO}_{2}-\mathrm{EOR}$ operations are $28 \%$ lower than those associated with a conventional oil production when the $\mathrm{CO}_{2}$ is sourced from a coal-fired power plant. . The results are broadly in line with those of an earlier study for the US National Energy Technology Laboratory (footnote a). A study of the Boundary Dam project in Saskatchewan in Canada found a reduction in emissions of up to $63 \% .^{\text {d }}$

a G. Cooney, J. Littlefield, J. Marriott, and T. Skone. 2015. Evaluating the Climate Benefits of $\mathrm{CO}_{2}$-Enhanced Oil Recovery Using Life Cycle Analysis. Environmental Science and Technology. 49 (12). pp. 7491-7500. https://pubs.acs.org/doi/ipdf/10.1021/acs.est.5boo700.

b International Energy Agency. 2015. Storing $\mathrm{CO}_{2}$ through Enhanced Oil Recovery: Combining EOR with $\mathrm{CO}_{2}$ Storage (EOR+) for Profit. Paris: Organisation for Economic Co-operation and Development and IEA.

c N. Azzolina, W. Peck, J. Hamling, C. Gorecki, S. Ayash, T. Doll, and L. Melzer. 2016. How Green is My Oil? A Detailed Look at Greenhouse Gas Accounting for $\mathrm{CO}_{2}$-Enhanced Oil Recovery ( $\mathrm{CO}_{2}$-EOR) Sites. International Journal of Greenhouse Gas Control. 51. pp. 369-379. https://www.sciencedirect.com/science/article/pii/S1750583616302985.

d A. Manuilova, J. Koiwanit, L. Piewkhaow, M. Wilson, C. Chan, and P. Tontiwachwuthikul. 2014. Life Cycle Assessment of PostCombustion $\mathrm{CO}_{2}$ Capture and $\mathrm{CO}_{2}$-Enhanced Oil Recovery based on Boundary Dam Integrated Carbon Capture and Storage Demonstration Project in Saskatchewan. Energy Procedia. 63. pp. 7398-7407.

Source: Authors. 
wells for the purpose of oil or gas-related recovery and is, therefore, a valid climate mitigation measure. ${ }^{7} \mathrm{CO}_{2}-\mathrm{EOR}+$ is one of the ways in which oil companies can reduce the emissions intensity of the oil they supply.

At a minimum, $\mathrm{CO}_{2}-\mathrm{EOR}+$ requires the $\mathrm{CO}_{2}$ to come from an anthropogenic source and to be otherwise emitted to the atmosphere as part of an industrial activity, such as a power station or industrial facility, including natural gas processing (gas extracted from a reservoir often contains significant amounts of $\mathrm{CO}_{2}$ ). If the $\mathrm{CO}_{2}$ comes from a dedicated natural source, as is often the case at present, $\mathrm{CO}_{2}-\mathrm{EOR}+$ is neither beneficial for the climate nor the development of CCS. For a project to qualify as $\mathrm{CO}_{2}$-EOR+ in practice, it would also require the gas being stored to be properly measured and verified.

The degree to which the injected $\mathrm{CO}_{2}$ can be permanently retained in the field is crucial to the attractiveness of $\mathrm{CO}_{2}-\mathrm{EOR}+$ as a climate change mitigation measure. A significant portion of the $\mathrm{CO}_{2}$ in the reservoir usually remains trapped, or "incidentally stored," due to capillary forces that act to immobilize its movement within pores in the rock and through dissolution in residual oil and water present in the reservoir (Melzer, 2012). For US projects, the share of injected $\mathrm{CO}_{2}$ left in the reservoir - the retention ratio-is initially close to $100 \%$, but then falls with successive injections to a floor level of between $40 \%$ and $60 \%$ (Azzolina et al., 2015; Kuuskraa, Leewen, and Wallace, 2011). To maintain pressure and production, the $\mathrm{CO}_{2}$ retained (stored) in the reservoir must be compensated through injection of additional $\mathrm{CO}_{2}$ or water. With each recovery cycle, a more or less constant share of the injected $\mathrm{CO}_{2}$ is eventually retained in the reservoir until a large volume is securely trapped (Azzolina et al., 2015). With recycling of the produced $\mathrm{CO}_{2}$ at the field same (or at other field in the vicinity) to minimize the cost of buying new supplies of $\mathrm{CO}_{2}$, virtually all of the injected gas is ultimately stored.

The volume of $\mathrm{CO}_{2}$ that is stored in this way depends on the properties of the reservoir and the oil it contains, and on operational factors of oil production, including the duration of the injections, well spacing, the relative position of the injection and producing wells, and, in the case of "water-alternating-gas," the ratio of water to $\mathrm{CO}_{2}$ used (International Energy Agency, 2015). Reducing the ratio allows more room in the reservoir for $\mathrm{CO}_{2}$ rather than water to fill the space left by the oil that is produced and, therefore, the amount of $\mathrm{CO}_{2}$ that can ultimately be stored in the field once production has ceased.

$\mathrm{CO}_{2}$-EOR always results in a large amount of $\mathrm{CO}_{2}$ being stored permanently in the field, even if operated in such a way as to maximize oil production without regard to how much $\mathrm{CO}_{2}$ is stored. But for the technology to function as $\mathrm{CO}_{2}-\mathrm{EOR}+$ and qualify as a genuine climate mitigation measure, several additional activities need to be undertaken before, during, and following $\mathrm{CO}_{2}$ injection, including additional

7 Government of the United States, Environmental Protection Agency. Memorandum to the Regional Water Division Directors regarding the Key Principles in EPA's Underground Injection Control Program Class VI Rule Related to Transition of Class II Enhanced Oil or Gas Recovery Wells to Class VI. Washington, DC: Office of Ground Water and Drinking Water. 23 April. https://www.epa.gov/sites/production/files/2015-07/documents/ class2eorclass6memo_1.pdf. 
measurement, reporting, and verification (MRV) activities. ${ }^{8}$ These include the following (Gupta et al., 2016):

(i) additional site characterization and risk assessment to collect information on geological formations, as well as abandoned wells, to assess the potential for leakage of $\mathrm{CO}_{2}$ from the reservoir; 9

(ii) additional measurement of venting and fugitive emissions from surface processing equipment;

(iii) enhanced monitoring and surveillance of the field to identify and, if necessary, estimate leakage rates; and

(iv) changes to abandonment processes, such as more robust sealing off of the well, including the removal of the uppermost components of wells so they can withstand the corrosive effects of $\mathrm{CO}_{2}$-water mixtures to ensure that the $\mathrm{CO}_{2}$ is stored permanently in the reservoir and does not leak out over time.

Economic factors affect the extent to which the operator of a $\mathrm{CO}_{2}-\mathrm{EOR}$ project seeks to maximize $\mathrm{CO}_{2}$ storage rather than oil production and to source the $\mathrm{CO}_{2}$ from anthropogenic rather than natural sources. The additional investment and activities required for the technology to work as $\mathrm{CO}_{2}-\mathrm{EOR}+$ represent an additional cost to the field operator. Changes in the way $\mathrm{CO}_{2}$ injection facilities are designed and operated to maximize the amount of gas stored may also incur significant additional costs. Similarly, at the end of operations, leaving as much $\mathrm{CO}_{2}$ as possible in the reservoir rather than maximizing recovery of the gas and reusing it elsewhere before shutting in the wells and abandoning the field would carry a cost.

For operators to opt for anthropogenic sources of $\mathrm{CO}_{2}$ and to maximize storage of that gas at all stages of the project cycle, they would either need to be given a financial incentive or be forced to do so through regulation (Ward et al., 2018). Incentives can take the form of carbon pricing, which would lower the price of $\mathrm{CO}_{2}$ supplies to EOR operators by creating an incentive for industrial emitters to capture the gas and seek a means of storing it, or a direct grant or tax credit per ton of $\mathrm{CO}_{2}$ stored (as is currently the case in the US). To be effective, the incentive needs to be greater than the additional costs associated with $\mathrm{CO}_{2}-\mathrm{EOR}+$ relative to the traditional process. Regulations requiring operators to maximize storage might achieve the same result but carry the risk of deterring investment in new $\mathrm{CO}_{2}-\mathrm{EOR}+$ projects and scaling back ongoing operations by rendering the process less profitable.

8 The MRV plan is a vital tool for operators of $\mathrm{CO}_{2}-\mathrm{EOR}+$ projects to proactively manage project risks. It is typically developed in consultation with regulatory authorities and lenders. Primary requirements would be reservoir zone monitoring to adequately track the pressure, temperature, and flow of $\mathrm{CO}_{2}$. Should leakage signals be detected, the second tier of monitoring for leakage detection and management would be implemented by monitoring above the reservoir zone; and, at the third tier, near-surface and surface monitoring would be carried out.

9 The condition of the well cement, casing, and plug determines if a well can sustain hydrostatic pressure and prevent leakage of fluids and gas (Haagsma et al., 2016). 


\section{Global Status and Prospects for Carbon Dioxide-Enhanced Oil Recovery}

$\mathrm{CO}_{2}-\mathrm{EOR}+$ is starting to take off as new projects are designed with the dual goal of boosting oil production and storing the $\mathrm{CO}_{2}$, usually in response to financial incentives. In most cases, this involves sourcing the $\mathrm{CO}_{2}$ from an industrial plant with capture facilities rather than a naturally occurring source. In some cases, field operations at existing $\mathrm{CO}_{2}$-EOR projects that were originally conceived with the sole objective of enhancing oil recovery are being modified to boost storage by modifying the source of the $\mathrm{CO}_{2}$ or injection operations.

According to the Global CCS Institute, which maintains a database of large-scale integrated facilities, ${ }^{10}$ there are currently $14 \mathrm{CO}_{2}-\mathrm{EOR}+$ projects in operation around the world with total injection capacity of around 35 MMT per year (Global CCS Institute, 2018). Ten of them are located in North America, of which eight are in the US (Table 1). Five of the US projects started after 2009. The Weyburn-Midale project was the first to be subject to an extensive pilot program to monitor and verify

\section{Table 1: Large-Scale Commercial Carbon Dioxide Capture Projects for Carbon Dioxide-Enhanced Oil Recovery}

\begin{tabular}{|c|c|c|c|}
\hline Country & Project & $\begin{array}{l}\text { Start } \\
\text { date }\end{array}$ & $\begin{array}{l}\text { Cumulative } \mathrm{CO}_{2} \\
\text { injection (MMT) }\end{array}$ \\
\hline \multirow[t]{2}{*}{ Canada } & $\begin{array}{l}\text { Great Plains Synfuels } \\
\text { (Weyburn-Midale) }\end{array}$ & 2000 & 40 \\
\hline & Boundary Dam (Weyburn-Midale) & 2014 & 2 \\
\hline \multirow[t]{8}{*}{ United States } & Terrell (formerly Val Verde) & 1970s & 20 \\
\hline & Enid & 1980s & $>10$ \\
\hline & Shute Creek & $1980 \mathrm{~s}$ & $>50$ \\
\hline & Century Plant & 2010 & 3 \\
\hline & Air Products SMR & 2013 & 4 \\
\hline & Lost Cabin & 2013 & 3 \\
\hline & Coffeyville Gasification & 2013 & 2 \\
\hline & Petra Nova & 2016 & 2 \\
\hline Brazil & Lula/Sapinhoa pre-salt & 2013 & 7 \\
\hline Saudi Arabia & Uthmaniyah (Ghawar) & 2015 & 2 \\
\hline United Arab Emirates & Abu Dhabi CCS & 2016 & 1 \\
\hline $\begin{array}{l}\text { People's Republic } \\
\text { of China }\end{array}$ & CNPC-Jilin & 2018 & 1 \\
\hline
\end{tabular}

$\mathrm{CCS}=$ carbon capture and storage, $\mathrm{CNPC}=$ China National Petroleum Corporation, $\mathrm{CO}_{2}=$ carbon dioxide, $M M T$ = million metric ton

Source: Global CCS Institute. 2018. The Global Status of CCS 2018. Melbourne. https://www. globalccsinstitute.com/resources/global-status-report/.

10 Defined as involving the capture, transport, and storage of $\mathrm{CO}_{2}$ at a scale of at least 800,000 metric tons (Mt)/ year for a coal-based power plant and 400,000 Mt/year for other emissions-intensive industrial facilities. 
the amount of $\mathrm{CO}_{2}$ being stored (Box 3).The most recent is the installation in 2017 of $\mathrm{CO}_{2}$ capture technology at the NRG Petra Nova power station in Texas, a combined 374-megawatt coal- and gas-fired plant, allowing the capture of $90 \%$ of the plant's emissions, or 1.8 MMT/year. ${ }^{11}$ The $\mathrm{CO}_{2}$ is compressed and transported via a 130-km pipeline to the West Ranch Oilfield, where it is used for $\mathrm{CO}_{2}$-EOR. Oil production at the field was increased by a factor of 13 to $4,000 \mathrm{~b} / \mathrm{d}$. The Texas Bureau of Economic Geology has put a monitoring plan in place to keep track of the injection and movement of the $\mathrm{CO}_{2}$ beneath the surface and in the rock structures at West Ranch. The project is expected to run for 20 years, involving up to 130 injection wells and 130 production wells.

Box 3: The International Energy Agency Greenhouse Gas Research and Development Program's Weyburn-Midale Carbon Dioxide Monitoring and Storage Pilot Project

The Weyburn and Midale oilfields, located in southeast Saskatchewan, Canada, were brought into primary production in 1954. As is common, oil was initially produced from the reservoir without injection of other fluids. After several years of operation, water flooding (a secondary recovery technique) was introduced to maintain production at both fields together with the drilling of additional (infill) wells to reach parts of the reservoir that had not been previously accessed. In October 2000, Cenovus (formerly PanCanadian or EnCana) began injecting carbon dioxide $\left(\mathrm{CO}_{2}\right)$ into the Weyburn field to boost oil production. There are now over 100 injection wells. Apache followed suit in 2005, injecting $\mathrm{CO}_{2}$ into the Midale field. The two fields combined are expected to produce at least 220 million barrels of incremental oil through miscible or near-miscible displacement with $\mathrm{CO}_{2}$, extending the life of the fields by 2 to 3 decades.

At the start of $\mathrm{CO}_{2}$ injection, a comprehensive monitoring and verification pilot program was launched by the International Energy Agency Greenhouse Gas (IEAGHG) Research and Development Program. Although monitoring of the stored $\mathrm{CO}_{2}$ halted in 2012 and the field is now operated as a traditional enhanced oil recovery (EOR) project, it has provided very useful insights into the potential of combining EOR with $\mathrm{CO}_{2}$ storage activities. Overall, it is estimated that around 40 million metric tons (MMT) of $\mathrm{CO}_{2}$ will be permanently sequestered over the project's lifespan-30 MMT at Weyburn and 10 MMT at Midale.

Source: B. Hitchon, ed. 2012. Best Practices for Validating CO Geological Storage: Observations and Guidance from the IEA GHG Weyburn-Midale $\mathrm{CO}_{2}$ Monitoring Project. Sherwood Park: Geoscience Publishing.

\footnotetext{
"NRG Energy, Inc. Petra Nova: Carbon Capture and the Future of Coal Power. https://www.nrg.com/case-
} studies/petra-nova.html. 
Four large-scale $\mathrm{CO}_{2}-\mathrm{EOR}+$ projects have been completed outside of North America:

(i) The Lula-Sapinhoa pre-salt oilfield in Brazil: This is the biggest $\mathrm{CO}_{2}$-EOR project of any kind in the world and a pioneer in using the technology in ultra-deep water. The project, which started in 2013, has boosted production by $100,000 \mathrm{~b} / \mathrm{d}$ using $\mathrm{CO}_{2}$ per year from a nearby offshore gas-processing plant. An estimated 2.5 MMT was injected in 2017 (Global CCS Institute, 2018). The project involves the deepest $\mathrm{CO}_{2}$ injection well currently operating in the world, at more than 5,000 meters below sea level.

(ii) The Uthmaniyah $\mathrm{CO}_{2}$-EOR demonstration project in Saudi Arabia: This project, which is being undertaken by Saudi Aramco (the national oil company), is capturing 0.8 MMT per year of $\mathrm{CO}_{2}$ from the existing Hawiyah natural gas processing plant and injecting it into the Uthmaniyah production unit of the super-giant Ghawar oilfield - the largest in the world..$^{12}$ The project involves piloting new technologies to monitor and verify the behavior of $\mathrm{CO}_{2}$ underground.

(iii) The Abu Dhabi CCUS project in the United Arab Emirates: This is the first fully commercial large-scale CCUS project in the iron and steel industry, having started operation in 2016. Some 0.8 MMT per year of high-purity $\mathrm{CO}_{2}$ produced as a by-product of the direct reduced iron-making process at the Emirates Steel Industries factory in Mussafah is captured, transported by pipeline, and injected into the Bab and/or Rumaitha fields by the Abu Dhabi National Oil Company for EOR. The project produced around 10,000 b/d of oil in 2017.

(iv) The Phase 3 Jilin project in the PRC: Operated by the China National Petroleum Corporation, the project started up in 2018, injecting 0.6 MMT per year of $\mathrm{CO}_{2}$ (combined with earlier small-scale demonstration phases, total cumulative injection reached 1.2 MMT in 2018).

In addition to existing $\mathrm{CO}_{2}$-EOR+ projects, five more commercial large-scale projects are currently under construction and due to be operational by 2020: two in Canada (the Alberta Carbon Trunk Line Sturgeon and Agrium projects), two in the PRC (at Qilu and Yanchang), and one in Norway (the Full Chain CCS facility) (Global CCS Institute, 2018). In addition, a number of countries, including India and Indonesia, are planning $\mathrm{CO}_{2}$-EOR+ pilot studies.

The long-term potential for $\mathrm{CO}_{2}$ storage through $\mathrm{CO}_{2}-\mathrm{EOR}+$ is highly uncertain as few studies have been carried out. According to the IEA, the global technical $\mathrm{CO}_{2}$ storage potential associated with $\mathrm{CO}_{2}-\mathrm{EOR}+$ projects (based on a field-by-field evaluation of suitability and capacity) could be very large, ranging from 60 gigatons (Gt) to $360 \mathrm{Gt}$ of $\mathrm{CO}_{2}$ between 2015 and 2065 (International Energy Agency, 2015). This equates to $50 \%$ to more than three times the $\mathrm{CO}_{2}$ storage requirement by 2050 in the IEA's Sustainable Development Scenario. In addition, exploiting this potential would raise oil production by up to 375 billion barrels over the period to 2065 , roughly three-quarters from onshore fields. This potential is not evenly distributed in the world, with North America, the Middle East, and the Russian Federation accounting

12 Carbon Sequestration Leadership Forum. Uthmaniyah Carbon Dioxide Enhanced Oil Recovery $\left(\mathrm{CO}_{2}\right.$-EOR) Demonstration Project. https://www.cslforum.org/cslf/Projects/Uthmaniyah. 
for the overwhelming bulk of it, measured by either oil production or $\mathrm{CO}_{2}$ storage. A more recent study estimates the economic storage potential outside North America at about $40 \mathrm{Gt}$ using currently operating emission sources based on an oil price of $\$ 50 /$ barrel and no penalties for $\mathrm{CO}_{2}$ emissions (Ward et al., 2018).

Exploiting this potential will depend on a host of economic factors and practical considerations. In many instances, it may not be economically viable to invest in $\mathrm{CO}_{2}$-EOR+, even where policy incentives or regulations are in place-especially if oil prices remain low. In the near term, another major barrier to investment in the technology outside of North America is an absence of technical capability. $\mathrm{CO}_{2}$-EOR has become a niche business among American oil and service companies, and the requisite skills, technologies, and expertise are not widely available elsewhere. Half a dozen midsize oil and gas companies currently operate the majority of $\mathrm{CO}_{2}$-EOR projects in the US (International Energy Agency, 2015). In addition, the deployment of $\mathrm{CO}_{2}$ capture facilities at industrial plants or power stations is at an early stage. As has proved to be the case with US shale oil and gas drilling, transferring technical capabilities in the field of $\mathrm{CO}_{2}$ capture and EOR to other regions will inevitably take time.

Despite these barriers, it is widely expected that oil production using $\mathrm{CO}_{2}-\mathrm{EOR}$ (including operations that combine long-term storage) will continue to expand over the coming decades. In its latest World Energy Outlook, the IEA projects continuing growth in global oil production from $\mathrm{CO}_{2}$-EOR from 0.46 million barrels of oil per day (Mb/d) in 2015 to $1.64 \mathrm{Mb} / \mathrm{d}$ in 2040 in its central scenario (the New Policies Scenario), which takes account of current policies and commitments (Figure 4). $\mathrm{CO}_{2}$-EOR becomes the leading type of EOR by the 2030s, overtaking thermal techniques (steam flooding). Nonetheless, this represents only a small fraction of the total technical potential. 
Figure 4: World Oil Production from Enhanced Oil Recovery by Type in the International Energy Agency's New Policies Scenario 6

5

4

$\frac{0}{2} 3$

2

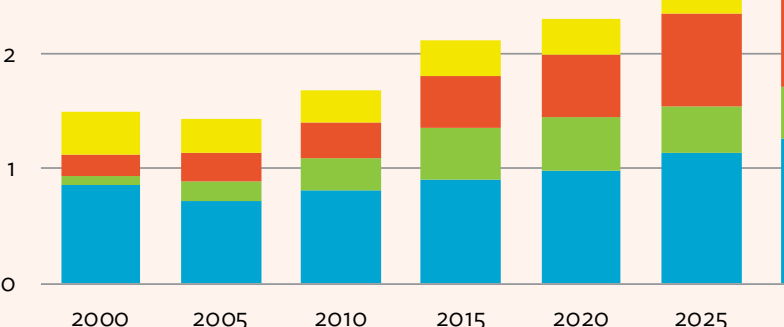

$2000 \quad 2005$

2010

2015

2020

2025

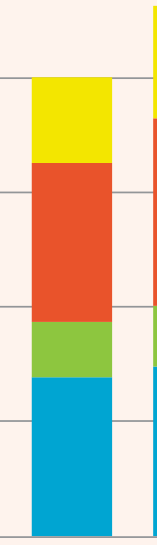

$2035 \quad 2040$

-Thermal EOR ChemicalEOR $\quad \mathrm{CO}_{2} \mathrm{EOR}$ Other gas EOR

$\mathrm{CO}_{2}=$ carbon dioxide, $\mathrm{EOR}$ = enhanced oil recovery, $\mathrm{Mb} / \mathrm{d}=$ million barrels of oil per day.

Source: C. McGlade, G. Sondak, and M. Han. 2018. Commentary: Whatever Happened to Enhanced Oil Recovery? IEA Newsroom. 28 November. https://www.iea.org/newsroom/news/2018/november/ whatever-happened-to-enhanced-oil-recovery.html. 


\section{CLIMATE POLICY IN INDONESIA}

\section{A. Trends in Energy Use and Greenhouse Gas Emissions}

Indonesia's energy use is likely to continue to grow briskly for the foreseeable future as its economy develops and population expands. Indonesia is currently one of the fastestgrowing economies in the world. According to official forecasts, Indonesia's economy is predicted to grow from the 11th largest at present to the 7th largest economy in the world by 2025 , with gross domestic product per capita increasing more than six-fold between 2010 and 2050 (Table 2). The population of Indonesia is approaching 250 million-the fourth largest in the world - and is projected to reach 307 million by 2050 .

Table 2: Indicators of Economic Development and Energy Use in Indonesia

\begin{tabular}{|lrrrrr|}
\hline & 2010 & 2020 & 2030 & 2040 & 2050 \\
\hline Population (millions) & 234 & 252 & 271 & 289 & 307 \\
\hline GDP per capita (\$ per capita) & 2,306 & 3,655 & 5,823 & 9,319 & 14,974 \\
\hline Electrification rate (\%) & 70 & 85 & 99 & 99 & 99 \\
\hline Poverty indicator (\%) & 12 & 8 & 3 & 3 & 2 \\
\hline
\end{tabular}

GDP = gross domestic product.

Sources: Government of Indonesia, Ministry of Energy and Mineral Resources of the Republic of Indonesia. 2014. Indonesia Energy Policy. Jakarta. https://eneken.ieej.or.jp/data/5587.pdf; and Institut Teknologi Bandung (ITB or Bandung Institute of Technology) and LEMIGAS. 2017. Knowledge Partnership Program: Promoting Carbon Capture and Storage in Indonesia. Jakarta: ITB/LEMIGAS.

Total primary energy demand has more than doubled since 1995, with most of the increase met by fossil fuels (coal, oil, and natural gas). One reason for this is the limited domestic availability of other fuels for powering the industry and transportation sectors, which account for a major part of the country's energy consumption. Indonesia is well endowed with coal, oil, and gas resources. In 2016, oil was the leading fuel in Indonesia's energy mix, meeting $31 \%$ of the country's total needs, followed by biomass (25\%), coal (19\%), and gas (17\%). Geothermal provided $8 \%$ and hydropower $1 \%$; the contribution of other renewables was negligible. Coal accounts for well over half of all the power generated in Indonesia.

The fuel mix shifted markedly over the 10 years to 2016, with the share of coal increasing sharply - mainly due to the rapid growth in demand for electricity - and the share of 
biomass falling with switching by households to modern forms of energy (Figure 4). The share of oil also fell, while that of gas increased slightly. Overall, the share of fossil fuels has been trending up since the 1990, reaching nearly $67 \%$ in 2017 , compared with 53\% in 1990 (Figure 5).

Figure 5: Historic Trends in Total Primary Energy Supply by Source in Indonesia

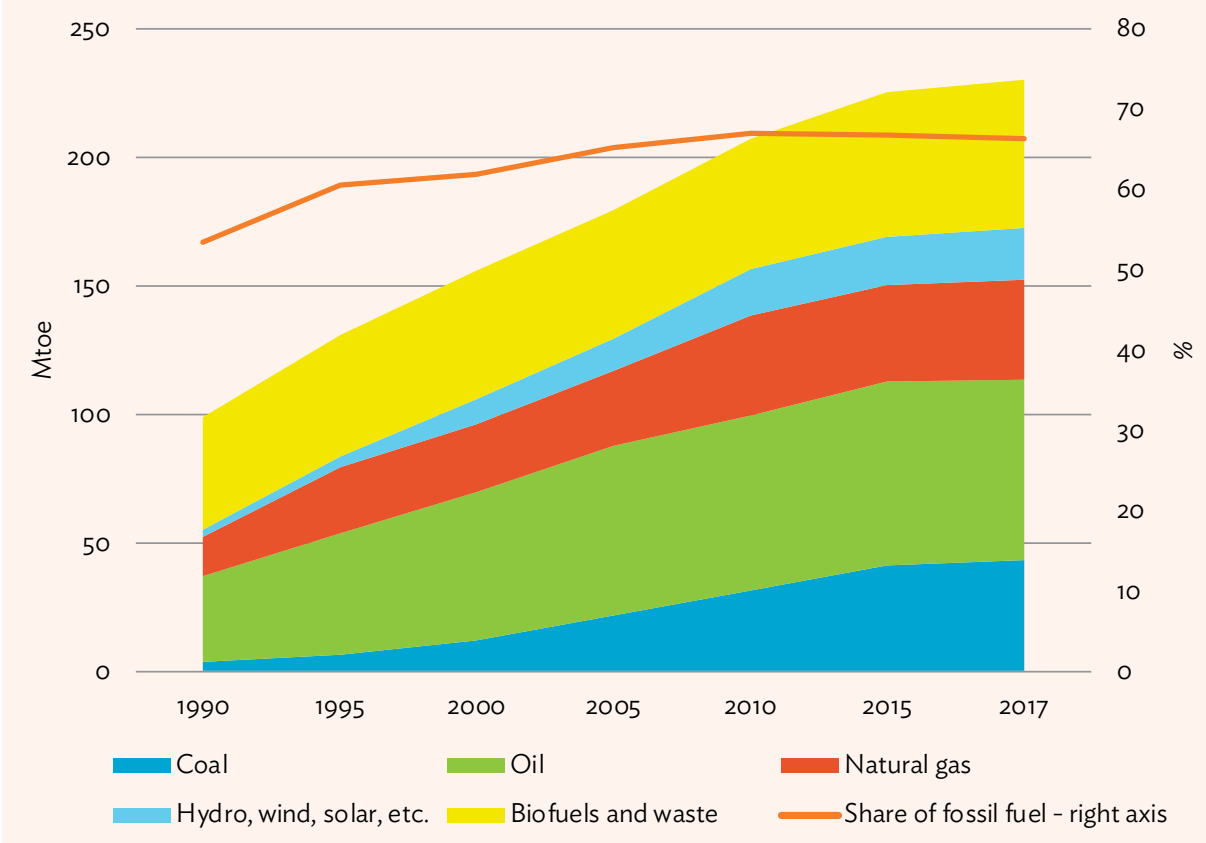

Mtoe $=$ millions of tons of oil equivalent.

Source: International Energy Agency (IEA). Total Primary Energy Supply (TPES) by Source, Indonesia 1990-2017. IEA Statistics. https://www.iea.org/statistics/ (accessed 14 October 2019).

In the absence of a radical change in government policy, energy use and GHG emissions in Indonesia are expected to continue to grow in the medium term in response to economic and population growth. According to official projections, Indonesia's energy demand, excluding noncommercial biomass, is set to more than double from 3.4 million barrels of oil equivalent per day (Mboe/d) in 2016 to $7.7 \mathrm{Mboe} / \mathrm{d}$ by 2025 (Figure 6). A large share of this increase is due to electricity consumption, which is set to continue to grow strongly. Energy needs for electricity generation are set to double between 2018 and 2026, from 290 terawatt-hours (TWh) to 562 TWh (PwC, 2017). Coal and gas are expected to remain the leading fuels in the power sector. The share of renewables, including wind and solar power, is projected to grow significantly, but fossil fuels are likely to continue to meet the bulk of the country's energy needs. Demand for petroleum-based transport fuels is also expected to continue to grow strongly (Badan Pengkajian dan Penerapan Teknologi, 2018). 
Figure 6: Projected Total Primary Energy Demand by Source in Indonesia

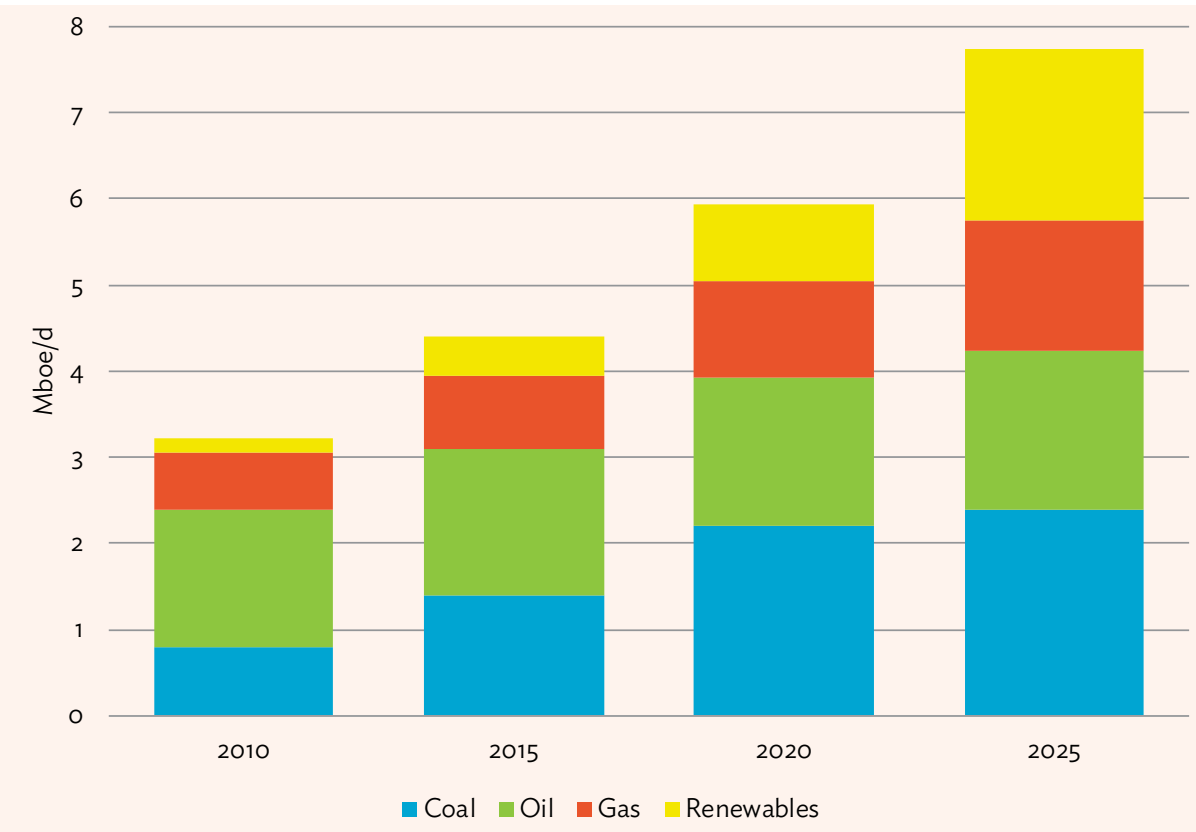

Mboe/d = million barrels of oil equivalent per day.

Note: Excludes noncommercial biomass.

Sources: For historical data, see Government of Indonesia, Ministry of Energy and Mineral Resources of the Republic of Indonesia (MEMRI). 2018. Handbook of Energy \& Economic Statistics of Indonesia. Final Edition. Jakarta. https://www.esdm.go.id/assets/media/content/content-handbook-of-energyand-economic-statistics-of-indonesia-2018-final-edition.pdf. For projections, see Government of Indonesia, MEMRI. 2014. Indonesia Energy Policy. Jakarta. https://eneken.ieej.or.jp/data/5587.pdf.

Continuing strong growth in the use of fossil fuels, led by coal, is set to push up GHG emissions at an even faster rate than energy demand. Indonesia is already the world's sixth-largest emitter of GHGs and the largest contributor of forest-based emissions. Energy use is the single largest source of the country's emissions, accounting for over one-third of the total. According to official projections, annual $\mathrm{CO}_{2}$ emissions from the energy sector are set to more than double between 2012 and 2025 to over $1.2 \mathrm{Gt}$, based on a reference scenario that assumes no change in policy (Wijaya et al., 2017).

\section{B. National Climate Mitigation Policy}

Given its growing importance in the world, Indonesia's success in meeting its national climate pledges will have a significant impact on future increases in global temperature. The Indonesian government is committed to addressing the impact of climate change by setting emissions reduction targets and devising a plan of action to ensure they are met. In 2010, it voluntarily pledged to reduce its GHG emissions unconditionally by $26 \%$ below a business-as-usual scenario by 2020 . In its nationally determined contribution (NDC) submitted to the United Nations Framework Convention on Climate Change in 2016, Indonesia committed to reduce its GHG 
emissions by $29 \%$ below its business-as-usual scenario by 2030 unconditionally and by up to $41 \%$ on condition that international support for finance, technology transfer, and capacity building is made available. ${ }^{13}$

The Government of Indonesia has adopted several measures designed to meet the commitments set out in the NDC. In the energy sector, notable recent moves include Government Regulation No. 72/2014 on National Energy Policy, which provides guidance on the development and transformation of Indonesia's energy sector in the face of rising demand for energy services, including a growing role for renewable energy. Subsequently, the government issued the regulation, which sets a target of producing at least 23\% of its energy mix from renewable energy (excluding noncommercial biomass) by 2025 and at least 31\% by 2050, compared with less than $6 \%$ in 2010 . It also aims to enhance energy security by reducing reliance on fossil fuels, targeting a fall in the share of the energy mix in 2025 to less than $25 \%$ for oil and $30 \%$ for coal, while that of gas is targeted to rise to $22 \%$. The targets for 2050 are $20 \%$ for oil, $25 \%$ for coal, and $24 \%$ for gas.

The government has since adopted two major measures to implement the Government Regulation No. 72/2014 on National Energy Policy. In 2016, the Ministry of Energy and Mineral Resources Decision No. 5899/K/20/MEM/2016 on Electricity Supply Business Plan year 2016-2023 was announced, establishing quotas for each type of generating plant to 2025 consistent with the targets set out in the Government Regulation No. 72/2014. And in 2017, the National Energy Plan (Presidential Regulation No. 22/2017 on National Energy Plan) was adopted to serve as reference for national and local governments, state-owned enterprises, and other stakeholders. The plan sets out detailed national and regional targets for each energy subsector and specific actions in end-use sectors, including energy efficiency and conservation measures. ${ }^{14}$

The government has emphasized that the country's contribution to meeting the goals of the Paris Agreement should not come at the cost of economic progress in view of the continuing need to address poverty. The Deep Decarbonization Pathways Project of the Institute for Sustainable Development and International Relations and the Sustainable Development Solutions Network proposes that, in Indonesia, priority should be given to cutting the carbon intensity of electricity generation, proposing a targeted reduction of $94 \%$ from 871 grams of $\mathrm{CO}_{2}$ per kilowatt-hour in 2010 to just 50 grams in 2050 (Siagian et al., 2015). This would require a wholesale shift to renewables and natural gas, as well as equipping coaland gas-fired power plants with carbon capture facilities. The study recognizes that, even with rigorous action to decarbonize the Indonesian economy, emissions will continue to increase until 2030 due to economic development, falling thereafter as a result of decarbonization measures.

13 United Nations Framework Convention on Climate Change. 2016. First Nationally Determined Contribution: Republic of Indonesia. November. https://www4.unfccc.int/sites/ndcstaging/PublishedDocuments/ Indonesia\%20First/First\%20NDC\%2OIndonesia_submitted\%20to\%20UNFCCC\%20Set_November\%20\%20 2016.pdf.

14 Government of Indonesia. n.d. New Paradigm of Indonesia Energy Policy and Planning. Jakarta: Indonesia National Energy Council. https://www.doe.gov.ph/sites/default/files/pdf/announcements/acd_14_new_ paradigm_indonesia_energy_policy_and_planning.pdf. 


\section{Role of Carbon Capture, Utilization, and Storage in Indonesia's Climate Strategy}

CCUS in the form of $\mathrm{CO}_{2}-\mathrm{EOR}+$ is a proven technology that could, in principle, contribute to Indonesia's climate mitigation efforts. Indonesia is a long-standing producer of crude oil, though production has been falling steadily for more than 20 years, having reached a plateau between 1977 and 1995, turning the country into a net oil importer. The government is seeking to boost oil production and reduce import dependence for economic and energy security reasons. There may be extensive opportunities for $\mathrm{EOR}$, including using $\mathrm{CO}_{2}$, given the maturity of many of the country's oilfields (Section IV. Potential for Carbon Dioxide-Enhanced Oil Reduction in Indonesia). $\mathrm{CO}_{2}$-EOR+ is a potentially attractive win-win solution for Indonesia, by halting the decline in oil production while addressing the urgent need to curb $\mathrm{CO}_{2}$ emissions.

Although CCUS has not been formally incorporated into the National Energy Plan, the government is looking at its potential to mitigate $\mathrm{CO}_{2}$ emissions in the long term. A study carried out for the Indonesian Ministry of Finance in 2015, which evaluated the pros and cons of pursuing deployment of the technology in the country, highlighted the opportunity to leverage global CCUS expertise and the potential to use it to improve coal bed methane production and other supply industries, but flagged concerns about its economic and technical viability, and the lack of any practical experience (Government of Indonesia, Ministry of Finance, 2015). The study recommended pilot testing to confirm the feasibility of storing $\mathrm{CO}_{2}$; to gain experience and expertise in operating a CCUS project and in measuring and verifying storage via $\mathrm{CO}_{2}$-EOR+ and other types of CCUS; to learn about the technical challenges, risks, costs, and funding requirements for such projects; and to assess the changes required in the regulatory and fiscal framework to promote large-scale deployment of the technology.

In recognition of the potential for CCUS to contribute to the decarbonization of the Indonesian energy sector, the Directorate General of Oil and Gas within the Ministry of Energy and Mineral Resources of the Republic of Indonesia (MEMRI) set up the Center of Excellence (CoE) for CCS and CCUS in Indonesia in 2017 to help facilitate the implementation of these technologies (Box 4). An initial study highlighted the scope for CCUS, notably $\mathrm{CO}_{2}-\mathrm{EOR}+$, in Indonesia given the extensive potential availability of anthropogenic sources of $\mathrm{CO}_{2}$ that would otherwise be emitted to the atmosphere, the opportunities for $\mathrm{EOR}$, and the possibility that $\mathrm{CO}_{2}-\mathrm{EOR}+$ could prove to be a low-cost climate mitigation option, where the revenues from enhanced oil production are sufficient to cover the cost of capturing and transporting $\mathrm{CO}_{2}$ to oilfields (ITB and LEMIGAS, 2017). Some potential pilot projects have already been identified (Section IV). 
Box 4: Indonesia's Center of Excellence for Carbon Capture and Storage and/or Carbon Capture, Utilization, and Storage

Indonesia's Center of Excellence (CoE) for carbon capture and storage (CCS) and carbon capture, utilization, and storage (CCUS) was created in 2017 by the director general of oil and gas under the Ministry of Energy and Mineral Resources of the Republic of Indonesia (MEMRI) to promote the collaboration on research and development between the Institut Teknologi Bandung (ITB or Bandung Institute of Technology) - the main Indonesian research institute in the field of CCS - and the Indonesian Research and Development Centre for Oil and Gas Technology (LEMIGAS) with the long-term aim of accelerating CCUS implementation in the country. The $\mathrm{CoE}$ has research divisions covering carbon dioxide $\left(\mathrm{CO}_{2}\right)$ capture; transportation; storage; well integrity; legal and regulatory matters (with participation from the Ministry of Environment and Forestry); financial analysis; Indonesia's nationally determined contribution (NDC); low-carbon development modeling; health, safety, and environment; risk assessment; risk communication; and measurement, monitoring and verification (with the participation of Pertamina University). Its advisory board includes representatives from government institutions and donor bodies, experts and academics. The steering committee is made up of the heads of the Coordinating Ministry of Economic Affairs, the Coordinating Ministry of Maritime Affairs, MEMRI, the Ministry of Environment and Forestry, SKK MIGAS (the regulator of the upstream oil and gas sector), and Pertamina (the state-owned oil and natural gas corporation).

Achievements to date include:

(i) the development and launch of an online knowledge portal;

(ii) a report on membrane-based $\mathrm{CO}_{2}$ capture technologies and a roadmap for their deployment;

(iii) a report on $\mathrm{CO}_{2}$ capture using potassium carbonate solvent with a boric acid promotor;

(iv) a draft regulation for CCS operations;

(v) a study on the potential contribution of CCS to Indonesia's NDC;

(vi) the organization of an annual knowledge workshop; and

(vii) technical inputs to CCUS pilot projects using $\mathrm{CO}_{2}$ from natural gas processing plants.

Source: Authors. 


\section{POTENTIAL FOR CARBON DIOXIDE-ENHANCED OIL RECOVERY IN INDONESIA}

\section{A. Potential for Enhancing Crude Oil Production}

Indonesia's oil industry is one of the oldest in the world, with commercial production beginning in 1885 . About $75 \%$ of exploration and production is located in Western Indonesia, with production concentrated in Sumatra, the Java Sea, East Kalimantan, and Natuna. There are around 60 sedimentary basins across the country, including 36 in Western Indonesia that have already been thoroughly explored; 14 of these are producing oil and gas (PwC, 2018). In underexplored areas of Eastern Indonesia, 39 tertiary and pretertiary basins may contain commercial quantities of hydrocarbons.

Oil production peaked in 1977 at over $1.6 \mathrm{Mb} / \mathrm{d}$ and has been declining steadily since the mid-1990s. Crude oil production averaged just over $800,000 \mathrm{~b} / \mathrm{d}$ in 2017 , down from $950,000 \mathrm{~b} / \mathrm{d}$ in 2007 . On a net basis, the country exported 53,000 b/d of crude oil in 2007 but imported $107,000 \mathrm{~b} / \mathrm{d}$ by 2017 -equal to around $12 \%$ of the country's consumption (Government of Indonesia, MEMRI, 2018b). Natural gas production has also been declining in recent years with the depletion of mature fields.

Proven oil reserves have been declining since 2008, from 5 billion barrels to 3.2 billion barrels in 2017 (Figure 7). The reserve replacement ratio (the share of the oil produced each year that is replaced with new reserves) has slipped to around 60\% (Rukmana, 2017). This is the result of the natural depletion of mature fields, which continue to account for the vast bulk of output, and a lack of investment, both in exploring for and developing new fields, and in applying secondary and tertiary recovery methods at existing fields. ${ }^{15}$ Deliberate cutbacks as required by the production sharing agreements of the Organization of the Petroleum Exporting Countries, of which Indonesia is a founding member, ${ }^{16}$ have also contributed to the recent slide in output. The recovery in international oil prices since 2016 may stimulate a modest recovery in upstream oil and gas investment in the near term.

The government is seeking to boost investment in the upstream sector to reverse the decline in production. It has declared several new strategic upstream oil and gas projects, such as the Jangkrik field development, Tangguh Train-3, the Indonesia Deepwater Development Project, and Genting's Kasuri block (PwC, 2017). It is also trying to encourage foreign investment in the upstream industry. It is looking at further changes in the new

15 The majority of Indonesian fields today have a water cut (the share of water in the total liquids produced) above $80 \%$ and, in some cases, as much as 99\%; 94\% of them are considered mature (Abdurrahman et al., 2017).

16 Indonesia suspended its membership in 2008 in response to falling production but rejoined in 2015. 
Figure 7: Remaining Proven Oil Reserves and Production in Indonesia

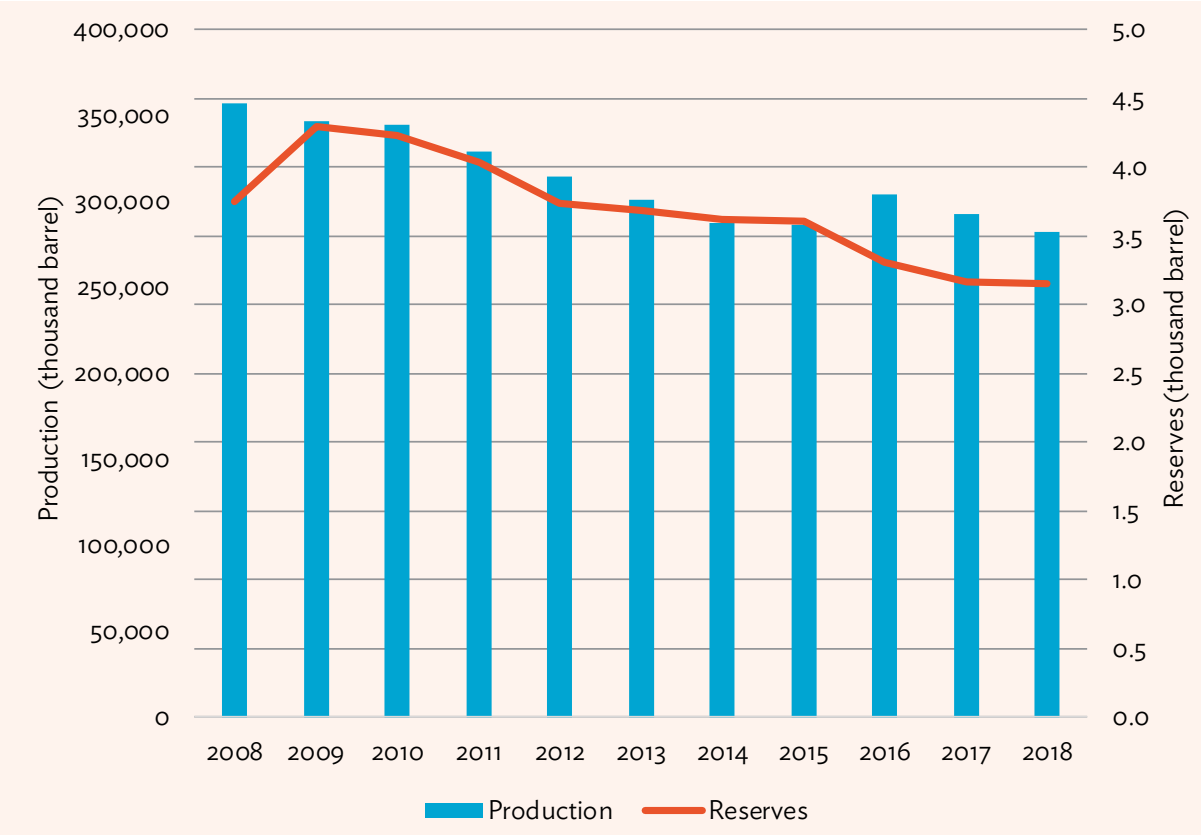

Source: Government of Indonesia, Ministry of Energy and Mineral Resources of the Republic of Indonesia. 2018. Handbook of Energy \& Economic Statistics of Indonesia. Final Edition. Jakarta. https:// www.esdm.go.id/assets/media/content/content-handbook-of-energy-and-economic-statistics-ofindonesia-2018-final-edition.pdf.

model adopted in early 2017 based on sharing gross production between the state and operators, as the licensing round launched in February 2018 resulted in only four of the 24 blocks on offer being awarded (International Energy Agency, 2018b). Attention is also being given to boosting existing technically recoverable reserves via infill wells and revitalizing production from mature wells by stepping up the use of secondary and tertiary recovery techniques. The Government of Indonesia has been encouraging oil companies operating in the country to use EOR (Abdurrahman et al., 2017).

In principle, many mature oilfields offer the potential for incremental oil production through $\mathrm{EOR}$, including $\mathrm{CO}_{2}$-EOR, which has not yet been deployed in Indonesia (ADB, 2013). The only experience Indonesia has with EOR of any kind on a commercial scale is steam flooding, which has been used for more than 30 years at the Duri oilfield - the largest project of its kind in the world. ${ }^{17}$ Chemical flooding using a combination of alkaline, surfactant, and polymers has also been piloted at three oilfields. Assuming that EOR methods are able to boost the recovery rate (the share of total resources originally in place that is producible) by $5 \%$ to $10 \%$, their implementation could lead to additional oil recovery of between 2.5 billion barrels

17 A chemical EOR pilot project was launched at the Duri field in 1975 but was not successful. Various other chemical pilot projects have been tested at other fields, including at Minas in 2013 and more recently at the Kaji and Semoga and the Meruap and Tanjung fields (Rukmana, 2017). In addition to these pilots, several laboratory and simulation studies were conducted or are currently underway in fields such as Handil and Limau. The first pilot gas injection EOR project, involving the reinjection of natural gas back into the reservoir, was successfully implemented in the Handil field in 1995 and has been underway since. 
and 5.0 billion barrels (Abdurrahman et al., 2017). Most Indonesian crude oil is medium-to-light, which is amenable to $\mathrm{CO}_{2}$-EOR, though-as in other countriesthe economics are highly dependent on the oil price and local factors, including the intrinsic characteristics of the reservoirs and the availability and cost of procuring $\mathrm{CO}_{2}$ (Muslim et al., 2013).

\section{B. Availability of Anthropogenic Carbon Dioxide}

The main potential sources of anthropogenic $\mathrm{CO}_{2}$ in Indonesia are natural gas and associated oil and gas processing plants, and industrial processes that involve the conversion of hydrocarbons, such as power stations and petrochemical plants, including fertilizer factories (Map 1). The gross output capacity from these sources combined throughout the country is estimated to be 6.8 billion cubic feet per day, or about 145 MMT per year (Putra, 2016). Power plants account for the bulk of this capacity (Table 3). All of the $\mathrm{CO}_{2}$ from these sources is currently released to the atmosphere.

Table 3: Anthropogenic Sources of Carbon Dioxide in Indonesia

\begin{tabular}{|c|c|c|}
\hline Source & $\begin{array}{l}\text { Estimated } \\
\text { emissions } \\
\text { (MMT/year) }\end{array}$ & Examples \\
\hline $\begin{array}{l}\text { Natural gas } \\
\text { processing }\end{array}$ & 2.8 & Subang, Merbau, Cilamaya, Gundih, JTB \\
\hline $\begin{array}{l}\text { Oil and LNG } \\
\text { processing }\end{array}$ & 17.3 & $\begin{array}{l}\text { LNG: Arun, Badak, Tangguh } \\
\text { Refineries: Sungai Paknik, Cilacap, Balikpapan, Balongan }\end{array}$ \\
\hline Power plants & 115.0 & Bangko Tengah, Muara Tawar, Indramayu, Muara Jawa \\
\hline Chemical plants & $\begin{array}{l}\text { No estimate } \\
\text { available }\end{array}$ & $\begin{array}{l}\text { Fertilizer plants: ASEAN \& PIM, Pusri, Kujang, Kaltim } \\
\text { Methanol plants: Bunyu } \\
\text { Petrochemicals: Gresik } \\
\text { Olefin centre: UP.IV Pertamina Cilacap } \\
\text { Polypropylene: UP.III Pertamina Plaju } \\
\text { Purified terephthalate acid: UP.III Pertamina Plaju }\end{array}$ \\
\hline Flared gas & 7.9 & Offshore gas blocks \\
\hline \multicolumn{3}{|c|}{$\begin{array}{l}\text { ASEAN = PT Asean Aceh Fertilizer (AAF), JTB = Jambaran-Tiung-Biru gas fields, LNG = liquified } \\
\text { natural gas, MMT = million metric ton, PIM = PT Pupuk Iskander Muda, UP.III = Unit Pengeloaan III } \\
\text { (Development Unit III), UP.IV = Unit Pengeloaan IV (Development Unit IV). }\end{array}$} \\
\hline \multicolumn{3}{|c|}{$\begin{array}{l}\text { Source: Battelle analysis based on Muslim et al. 2013. Opportunities and Challenges of } \mathrm{CO}_{2} \text { Flooding } \\
\text { in Indonesia. Paper presented at the Society of Petroleum Engineers Asia Pacific Oil and Gas } \\
\text { Conference and Exhibition. Jakarta. 23-24 October. https://www.academia.edu/10778808/ } \\
\text { Opportunities_and_Challenges_of_CO2-EOR_in_Indonesia. }\end{array}$} \\
\hline
\end{tabular}

The processing of natural gas is likely to be the cheapest source of high-purity $\mathrm{CO}_{2}$ now and in the future. The $\mathrm{CO}_{2}$ has to be removed before natural gas can be distributed and consumed, so that the only additional costs are purifying and transporting it to the oilfield for injection. Emissions from such plants, including the 


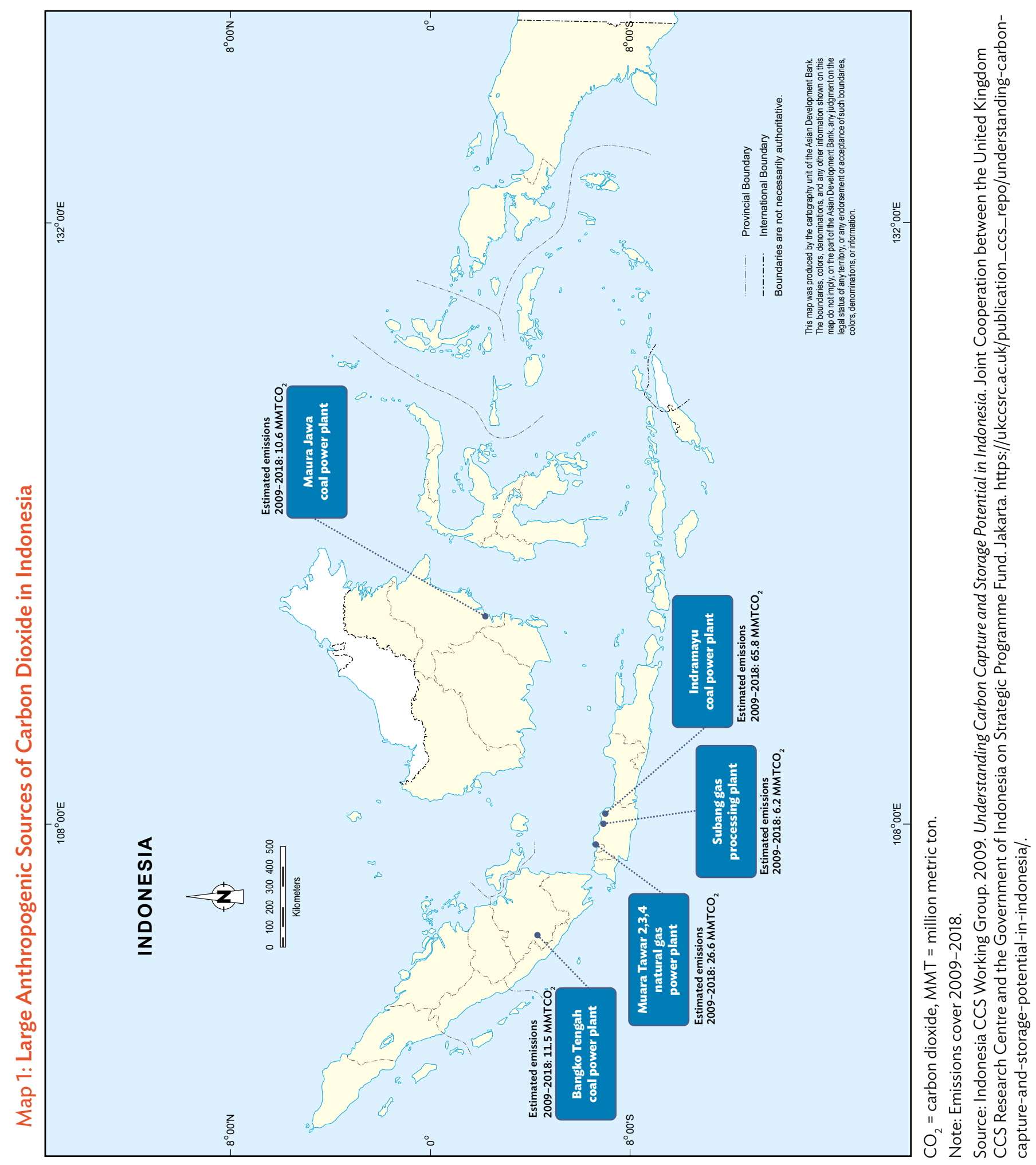


large Cilamaya, Gundih, Merbau, and Subang facilities, currently amount to around 2.8 MMT/year. A gas-processing plant at the Jambaran-Tiung-Biru field, construction of which is underway, could provide another $2 \mathrm{MMT} /$ year. The availability of $\mathrm{CO}_{2}$ from gas processing is likely to grow as several of the gas fields that are expected to come on stream in the coming years have particularly high $\mathrm{CO}_{2}$ content. One example is the East Natuna field-a large, as yet undeveloped, gas field located offshore north of the island of Natuna. ${ }^{18}$

The processing of natural gas used to produce liquefied natural gas and the processing of crude oil in refineries represent an additional potential source of low-cost $\mathrm{CO}_{2}$ that would otherwise be emitted. The total amount of $\mathrm{CO}_{2}$ available from these sources is estimated at over $17 \mathrm{MMT} /$ year. Around $8 \mathrm{MMT} /$ year of $\mathrm{CO}_{2}$ contained in natural gas that is currently being flared could also be used for $\mathrm{CO}_{2}$-EOR+. The cost of capturing and supplying $\mathrm{CO}_{2}$ from other sources, especially power plants, where dedicated capture facilities would need to be installed, is likely to be much higher as the concentration of $\mathrm{CO}_{2}$ in flue gases is generally much lower, except where separation and compression form a necessary part of the industrial process.

\section{Candidate Oilfields for Carbon Dioxide-Enhanced Oil Recovery Projects}

Identifying candidate oilfields for deploying $\mathrm{CO}_{2}-\mathrm{EOR}+$ in Indonesia needs to take account of both economic and technical considerations. The maturity of most of Indonesia's oilfields and the large amount of oil remaining in them suggest that there is significant technical potential, though the economic potential is likely to be far smaller, especially at low oil prices. As in other parts of the world, the economic viability of $\mathrm{CO}_{2}-\mathrm{EOR}+$ in Indonesia is also likely to hinge critically on the cost of procuring the $\mathrm{CO}_{2}$, which, in turn, depends on the distance over which it needs to be transported (as well as the volumes involved and the cost of capture). The closer the source of low-cost $\mathrm{CO}_{2}$, the more attractive such an investment will be. It follows, therefore, that the most promising candidates for $\mathrm{CO}_{2}-\mathrm{EOR}+$ projects are mature fields with declining production that are located in close vicinity to low-cost sources of $\mathrm{CO}_{2}$, such as natural gas processing plants.

Sumatra appears to be one of the most promising basins for $\mathrm{CO}_{2}-\mathrm{EOR}+$, notably the southern part (ADB, 2013; Putra, 2016; ITB and LEMIGAS, 2017). In addition to the large number of partially depleted oil and gas fields in the region and the existence of major gas-processing plants, South Sumatra has a low population density compared with the rest of the country, well-developed transportation infrastructure, and a relatively stable geology, being distant from seismic and tectonic activity. ${ }^{19}$ In its 2013

\footnotetext{
18 The field was discovered in 1973, but the high $\mathrm{CO}_{2}$ content of the natural gas has so far prevented development of the field. In 2011, an agreement to develop the field was signed between Pertamina (the largest investor), ExxonMobil, Total, and Petronas (later replaced by PTT Exploration and Production), but negotiations over a production sharing contract failed. ExxonMobil and PTT pulled out of the consortium in 2017.

19 Government of Indonesia, MEMRI. 2018. Current Status and Future Path of Developments for CCUS in Indonesia. Jakarta: LEMIGAS Research and Development for Oil and Gas. 8 June. https://d2ocoihd6a5bt.cloudfront.net/ wp-content/uploads/sites/837/2018/06/Usman-Pasarai-Current-Status-and-Future-Path-of-Developmentsfor-CCUS-in-Indonesia.pdf.
} 
study of the potential for CCS in Indonesia, ADB estimated that nearly 90 MMT of $\mathrm{CO}_{2}$ could be stored in oilfields and 830 MMT of capacity in gas fields in South Sumatra, many of these fields offering opportunities for $\mathrm{CO}_{2}$-EOR+ (ADB, 2013) ${ }^{20} \mathrm{It}$ recommended pursuing a pilot project based on captured $\mathrm{CO}_{2}$ from a gas-processing plant matched with storage in a nearby oilfield. LEMIGAS estimates that the total storage capacity in oil and gas fields amounts to nearly 485 MMT in the Sumatra basins (north, central, and south), compared with 106 MMT in the Java basin and 130 MMT in the Kutai basin (Map 2). It reckons that $\mathrm{CO}_{2}$-EOR+ could boost oil reserves in South Sumatra by as much as 480 million barrels and store around 75 MMT of $\mathrm{CO}_{2}$. Nationally, additional oil reserves could amount to 2 billion barrels with associated $\mathrm{CO}_{2}$ storage of 300 million tons (footnote 19).

Preliminary studies have already been conducted to evaluate the feasibility of CCUS and to identify potentially suitable sites, linking sources of $\mathrm{CO}_{2}$ to specific oilfields and other sinks. One such study carried out by LEMIGAS paired potential candidate fields for $\mathrm{CO}_{2}$-EOR+ with $\mathrm{CO}_{2}$ sources by drawing $150-\mathrm{km}$ and $300-\mathrm{km}$ circles around the most promising sources and ranking the candidate fields by proximity and by their infrastructure (Putra, 2016). Based on this analysis, it is calculated that close to 1 billion barrels could be recovered from 22 fields using $\mathrm{CO}_{2}-\mathrm{EOR}+$, with around $50 \mathrm{MMT}$ of $\mathrm{CO}_{2}$ injected each year (Table 4). Most of the $\mathrm{CO}_{2}$ would come from coal-fired power stations, including up to $11 \mathrm{MMT}$ /year of $\mathrm{CO}_{2}$ from the Bangko Tengah Power Plant in South Sumatra. In addition, the huge East Natuna gas field (not included in this analysis as it has yet to obtain the green light for development) could provide $40 \mathrm{MMT} /$ year; the primary candidate for use of this gas for $\mathrm{CO}_{2}$-EOR+ is the Seria field in onshore Brunei. This field has an estimated 2 billion barrels of oil in place, about half of which has been extracted to date, with the potential for additional recovery, with EOR, of around 500 million barrels.

More recently, the CoE has also evaluated Indonesian sedimentary basins for the suitability of deploying $\mathrm{CO}_{2}-\mathrm{EOR}+($ ITB and LEMIGAS, 2017). The results indicate that there is a priori a significant opportunity to boost oil production while storing large amounts of $\mathrm{CO}_{2}$ in the reservoirs. Scoring criteria were developed to rank oilfields based on their geological setting, petro-physical characteristics, reservoir rock and fluid properties, and $\mathrm{CO}_{2}$ storage availability. On this basis, the Kutei, South Sumatra and Central Sumatra basins were found to be the most suitable for a pilot project.

Owing to its large storage potential, the Kutai basin was selected for more detailed evaluation of the feasibility of $\mathrm{CO}_{2}$-EOR based on standard technical criteria developed by Taber (1997). The evaluation was then narrowed down to the Attaka, Bekapai, and Handil fields (the three largest in the basin), which were subject to reservoir engineering analyses to simulate the impact of $\mathrm{CO}_{2}$ and water injection on oil recovery (Table 5). The total $\mathrm{CO}_{2}$ storage potential in those three fields is estimated at over 350 MMT. Pertamina has also carried out laboratory and simulation $\mathrm{CO}_{2}$ injection studies of the Jatibarang, Gemah, and Beringin fields (Rukmana, 2017).

\footnotetext{
${ }^{20}$ An additional $7.6 \mathrm{Gt}$ of captured $\mathrm{CO}_{2}$ could be stored in saline reservoirs and $2.7 \mathrm{Gt}$ in coal beds.
} 


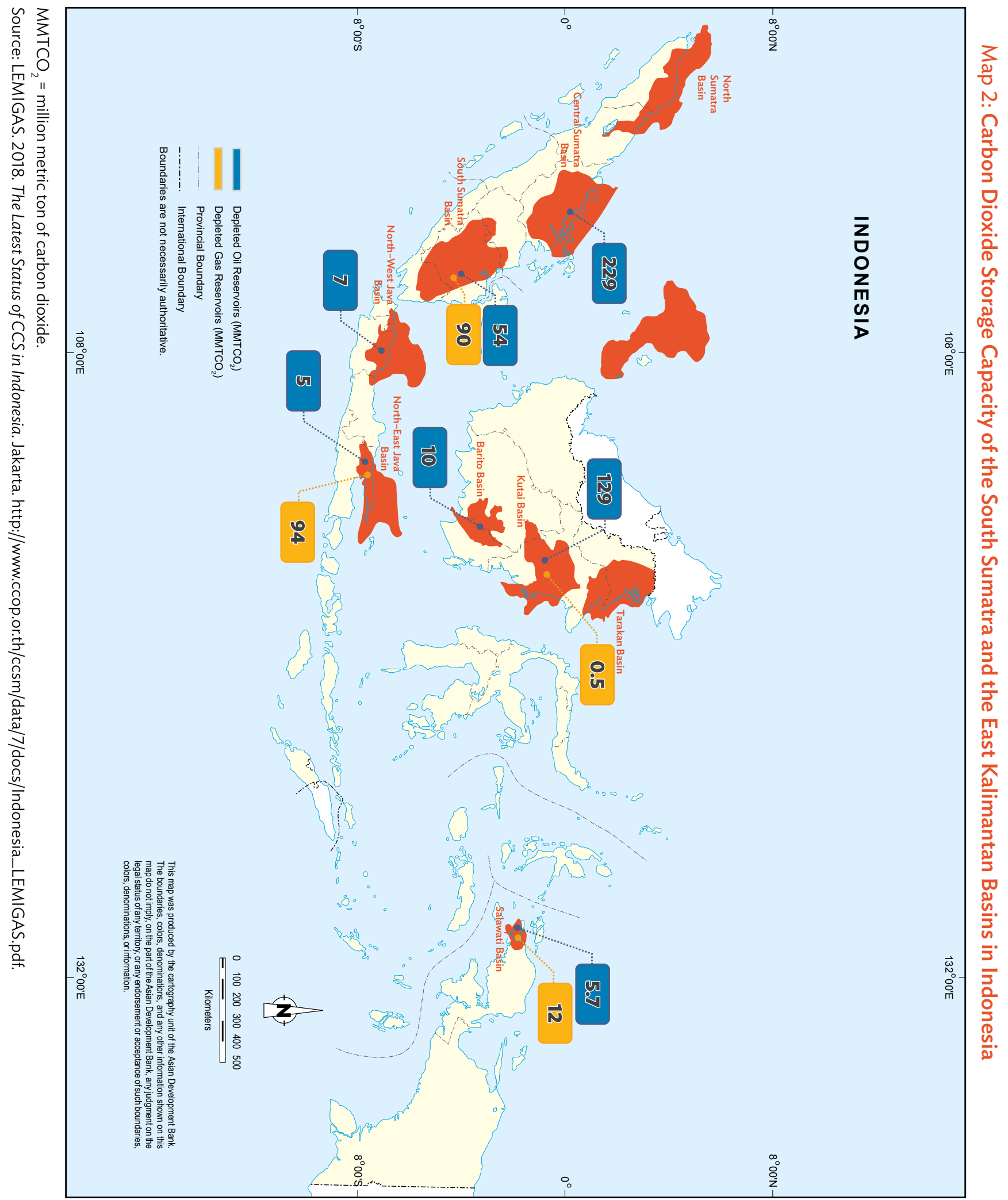


Table 4: Pairing of Carbon Dioxide Sources and Candidate Oilfields for Carbon Dioxide Enhanced Oil Recovery in Indonesia

\begin{tabular}{|c|c|c|c|c|c|}
\hline Basin & Sources of $\mathrm{CO}_{2}$ & $\begin{array}{l}\mathrm{CO}_{2} \\
\text { availability } \\
\text { (MMT/year) }\end{array}$ & $\begin{array}{l}\text { Candidate } \\
\text { oilfields for EOR }\end{array}$ & $\begin{array}{l}\text { Oil originally } \\
\text { in place } \\
\text { (million } \\
\text { barrels) }\end{array}$ & $\begin{array}{c}\text { Expected } \\
\text { recovery } \\
\text { with EOR } \\
\text { (million } \\
\text { barrels) }\end{array}$ \\
\hline $\begin{array}{l}\text { South } \\
\text { Sumatra }\end{array}$ & $\begin{array}{l}\text { Bangko Tengah } \\
\text { Power Plant, } \\
\text { Associated gas } \\
\text { from Jabung } \\
\text { Blocks (corridor } \\
\text { wells), and } \\
\text { Lematang Block } \\
\text { (Singa and } \\
\text { Harimau fields) }\end{array}$ & 14 & $\begin{array}{l}\text { Ramba, Kenali } \\
\text { Asam, Tempino, } \\
\text { Raja, Niru, } \\
\text { Abab, Limau } \\
\text { Tengah, G. } \\
\text { Kemala, Tanjung } \\
\text { Tiga, Bajubang, } \\
\text { Meruap, Kluang, } \\
\text { Beringin }\end{array}$ & 2,200 & 550 \\
\hline $\begin{array}{l}\text { West } \\
\text { Java }\end{array}$ & $\begin{array}{l}\text { Muara Tawar } \\
\text { Power Plant, } \\
\text { Subang Gas } \\
\text { Processing Plant }\end{array}$ & 33 & $\begin{array}{l}\text { Jatibarang, } \\
\text { X-Ray, Tambun, } \\
\text { Cemara, Tugu } \\
\text { Barat A }\end{array}$ & 1,200 & 300 \\
\hline East Java & $\begin{array}{l}\text { Gundih Natural } \\
\text { Gas Processing } \\
\text { Plant }\end{array}$ & 0.2 & $\begin{array}{l}\text { Mudi, Sukowati, } \\
\text { Kawengan, } \\
\text { Nblobo }\end{array}$ & 860 & 215 \\
\hline \multicolumn{6}{|c|}{$\mathrm{CO}_{2}=$ carbon dioxide, $\mathrm{EOR}=$ enhanced oil recovery, $\mathrm{MMT}=$ million metric ton. } \\
\hline \multicolumn{6}{|c|}{$\begin{array}{l}{ }^{b} \text { Assumed to be } 25 \% \text { of the oil in place based on a combined primary and secondary recovery rate of } \\
35 \% \text { and an ultimate recovery rate after EOR of } 60 \% \text {. }\end{array}$} \\
\hline \multicolumn{6}{|c|}{$\begin{array}{l}\text { Source: Battelle analysis based on E. Putra. 2016. Evaluation of } \mathrm{CO}_{2}-E O R \text { Injection and Its Potential } \\
\text { Application to Indonesia. Houston: Enerproco. http://siephouston.org/wp-content/uploads/2017/06/ } \\
\text { CO2-EOR-SIEPH-Putra.pdf. }\end{array}$} \\
\hline
\end{tabular}

Table 5: Evaluation of Carbon Dioxide-Enhanced Oil Recovery Potential at Oilfields in the Kutai Basin in East Kalimatan, Indonesia

\begin{tabular}{|c|c|c|c|c|c|c|}
\hline Field & $\begin{array}{l}\text { Oil originally } \\
\text { in place } \\
\text { (million } \\
\text { barrels) }\end{array}$ & $\begin{array}{l}\text { Injection rate } \\
\text { (tons/day) }\end{array}$ & $\begin{array}{l}\text { Injection } \\
\text { period } \\
\text { (years) }\end{array}$ & $\begin{array}{l}\text { Primary } \\
\text { production } \\
\text { (million } \\
\text { barrels) }\end{array}$ & $\begin{array}{l}\text { EOR } \\
\text { production } \\
\text { (million } \\
\text { barrels) }\end{array}$ & $\begin{array}{l}\mathrm{CO}_{2} \text { used/ } \\
\text { stored } \\
(\mathrm{MMT})\end{array}$ \\
\hline Attaka & 1,536 & 15,940 & 26.0 & 373 & 316 & 150 \\
\hline Handil & 1,457 & 22,110 & 20.0 & 884 & 351 & 159 \\
\hline Bekpai & 324 & 19,950 & 4.5 & 161 & 70 & 33 \\
\hline
\end{tabular}

$\mathrm{CO}_{2}=$ carbon dioxide, $\mathrm{EOR}=$ enhanced oil recovery, $\mathrm{MMT}=$ million metric ton .

Source: Institut Teknologi Bandung (ITB or Bandung Institute of Technology) and LEMIGAS. 2017.

Knowledge Partnership Program: Promoting Carbon Capture and Storage in Indonesia. Jakarta: ITB/

LEMIGAS. 
LEMIGAS subsequently identified the Beringin field, operated by Pertamina, in southern Sumatra with $\mathrm{CO}_{2}$ supplied from the company's nearby Merbau gas processing plant (gas gathering station) as another candidate for a pilot $\mathrm{CO}_{2}-\mathrm{EOR}+$ project. ${ }^{21}$ The cost of procuring the $\mathrm{CO}_{2}$ and Pertamina's interest in pursuing $\mathrm{CO}_{2}$-EOR were factors in this decision. The project would make use of the $\mathrm{CO}_{2}$ currently produced at the gas processing plant at Merbau. The plant has a single processing train, which separated out 28,800 tons ( 79 tons/day) of almost pure $\mathrm{CO}_{2}$ in 2016. ${ }^{22} \mathrm{All}$ of the $\mathrm{CO}_{2}$ is currently vented to the atmosphere. The pilot project envisages that 75 tons/day of this $\mathrm{CO}_{2}$ would be liquefied/chilled and then transported by road tanker to the Beringin oilfield located $65 \mathrm{~km}$ away. Existing wells at the field would be modified to create one injection well and four producing wells. It is envisaged that injection would last for 5 years, boosting the recovery factor at the field by 1.4 percentage points to around $3.4 \%$ and yielding around 53,000 extra barrels of oil. The process would be immiscible (i.e., not involving any mixing of the $\mathrm{CO}_{2}$ and oil), as the pressure in the reservoir is not high enough and the oil too heavy to permit any significant degree of miscibility. After 5 years, it is estimated that around 90,000 tons of $\mathrm{CO}_{2}$ would be retained (stored) in the field.

At the end of 2018, LEMIGAS decided to focus its efforts on supporting a pilot project at the Sukowati oilfield located in East Java (Map 3) due its greater potential for full-scale commercial application. The Sukowati field has been in production decline for several years, reaching around $9,000 \mathrm{~b} / \mathrm{d}$ at present-down from a peak of $46,137 \mathrm{~b} / \mathrm{d}$ in 2011 . Associated gas production is running at 13 million cubic feet per day-less than half its historic peak in 2011. The current recovery factor from the field is about $39 \%$. Around $219,000 \mathrm{~b} / \mathrm{d}$ of water is currently being injected into the field to boost production. ADB is providing technical assistance to Pertamina EOR-the owner and operator of the field-and the CoE to support the development of the proposed pilot project. Pertamina conducted a full field-scale pre-feasibility evaluation of the project in 2016. Battelle subsequently carried out a review of the pilot project on behalf of ADB based on information provided by Pertamina and its associates, which broadly confirmed the technical and economic viability of the project and identified the need for further action in key areas (Section V. Next Steps).

The Sukowati pilot project consists of a total of five existing wells: four production wells spaced out in the form of a square and a fifth (currently not in production) that would be converted to $\mathrm{CO}_{2}$ injection well. Like the Beringin project, the process would be immiscible as the current reservoir pressure is below the minimum miscibility pressure (MMP) and the producing area is not confined such that the injected $\mathrm{CO}_{2}$ and the accompanying pressure plume (pocket of gas) are able to migrate away from the producing wells. If the pilot proves to be successful, a commercial-scale project using a miscible process could be deployed, involving the use of all 35 existing production wells and drilling new $\mathrm{CO}_{2}$ and water injection wells. All of the $\mathrm{CO}_{2}$ for the pilot project would be sourced from the Sukowati field itself; the

\footnotetext{
${ }^{21}$ LEMIGAS has proposed another pilot project involving dedicated storage (with no $\mathrm{CO}_{2}$-EOR). It plans to capture 20,000 tons of $\mathrm{CO}_{2}$ from the natural gas processing plant at Gundih in Central Java and inject and store it in the nearby Ngrayong sandstone formation. Injection would last for 2 years followed by a period of monitoring.

${ }^{22}$ The removal of $\mathrm{CO}_{2}$ takes place in an absorber column by using a multi-stage proprietary A-MDEA (Active Methyl Diethanol Amine) process, producing a $\mathrm{CO}_{2}$ stream with a purity of $99.9 \%$ (footnote 19 ).
} 


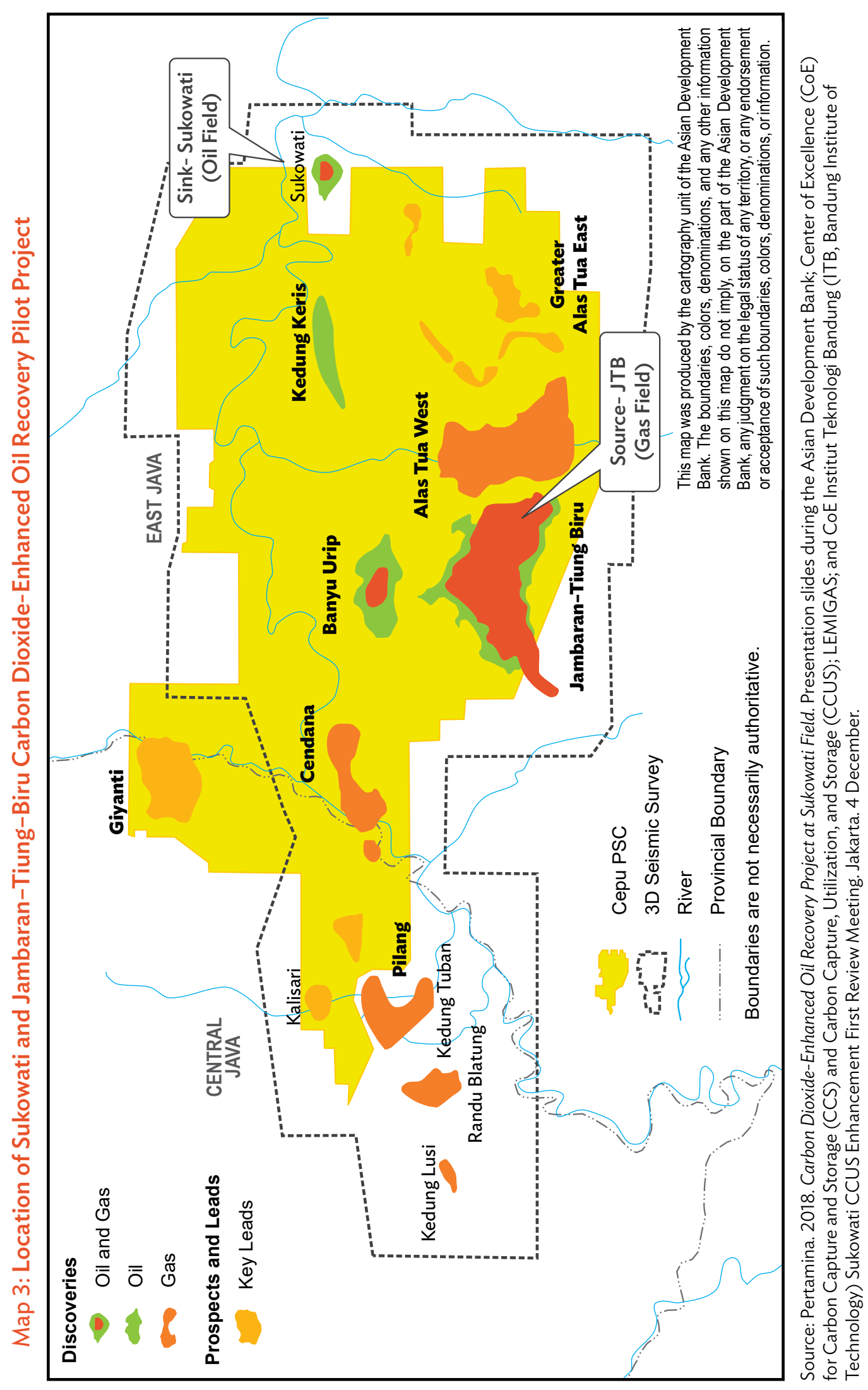


associated gas currently extracted from the field contains about $40 \% \mathrm{CO}_{2}$ (around 5 million standard cubic feet per day [mmscf/d], or 95,000 tons per year), which is stripped from the gas before sales. Additional gas that would be needed for the fieldscale project (up to $95 \mathrm{mmscf} / \mathrm{d}$ or $1.8 \mathrm{MMT} /$ year) would come from the nearby JTB gas-processing plant currently under construction - the largest of several potential sources of anthropogenic $\mathrm{CO}_{2}$ in the area.

Pertamina estimates that the full field-scale deployment of $\mathrm{CO}_{2}$-EOR would increase oil recovery from the field by an additional 50 million barrels, raising the recovery rate by 16.8 percentage points. It is estimated that the field is capable of storing up to $1,260 \mathrm{MMT}$. A project involving the highest proposed rate of injection $(100 \mathrm{mmscf} / \mathrm{d}$, or $1.9 \mathrm{MMT} /$ year) would require an estimated $\$ 440$ million of capital expenditure and $\$ 797$ million of operating expenditures over an assumed project lifetime of 15 years. 


\section{NEXT STEPS}

\section{A. Pilot Studies and Demonstration Projects}

The critical first step in the process of developing $\mathrm{CO}_{2}-\mathrm{EOR}+$ in Indonesia is to launch an initial pilot project. Commercial projects will only follow if at least one pilot and demonstration project has been operating successfully for several years. Such projects will require detailed design, cost estimates, and business plans, as well as environmental impact assessments. The learning and experiences from the pilot and demonstration projects will be of enormous value in helping operators prepare these inputs. ADB has previously proposed a generic road map for the development of CCUS generally, applicable to Indonesia and three other Southeast Asian countries that were selected for study (the Philippines, Thailand, and Viet Nam), stretching over 15 years (ADB, 2013). It includes a timeline for all activities relating to project development (Figure 8 ).

Pilot projects, which typically would be expected to involve the use of around 5-7 injection and producing wells, are important, not just as a way of proving the viability of the technology on a small scale, but also as a means of building in-country technical knowledge, understanding, and capability, as well as a broader understanding of the value and

Figure 8: Roadmap for the Development of Carbon Capture, Utilization, and Storage in Southeast Asian Countries

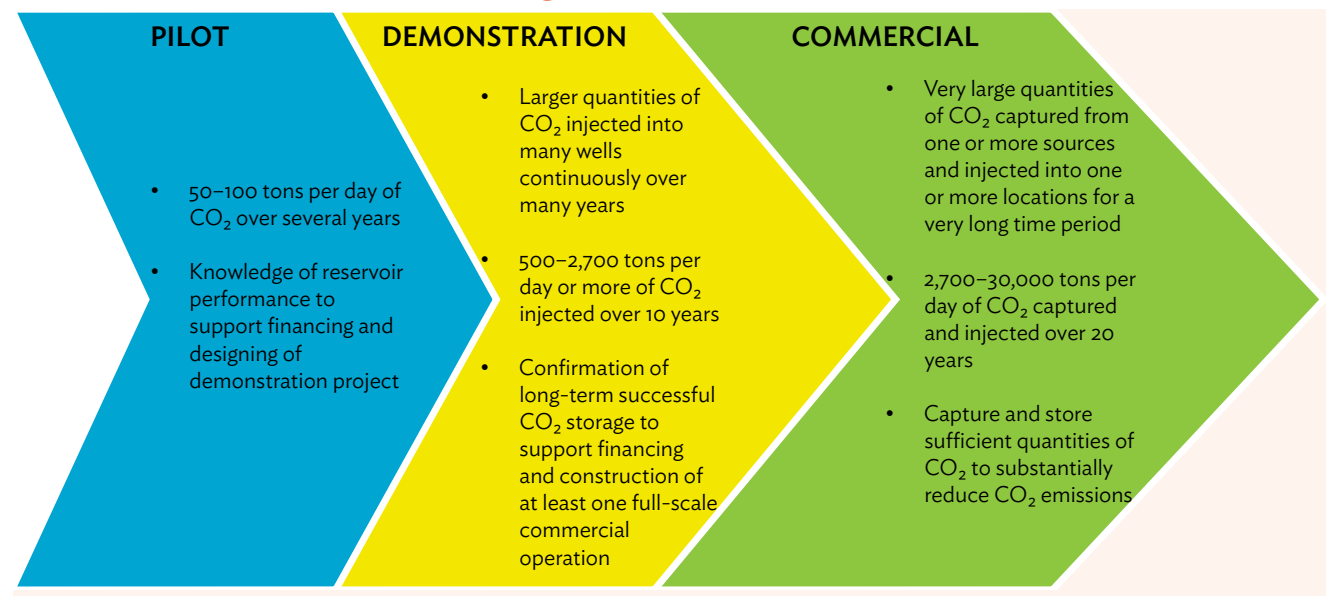

$\mathrm{CO}_{2}=$ carbon dioxide .

Source: Asian Development Bank. 2013. Prospects for Carbon Capture and Storage in Southeast Asia. Manila. https://www.adb.org/sites/default/files/publication/31122/carbon-capture-storage-southeast-asia.pdf. 
future role of $\mathrm{CO}_{2}-\mathrm{EOR}+$. The primary goal of these projects would be to demonstrate several aspects of the technology, including:

(i) $\mathrm{CO}_{2}$ sourcing from a nearby anthropogenic source;

(ii) transportation of the $\mathrm{CO}_{2}$ from the source to injection wells at the selected oilfields;

(iii) injection of $\mathrm{CO}_{2}$ in a way that minimizes health and environmental risks;

(iv) tracking reservoir response to $\mathrm{CO}_{2}$ injection in terms of incremental oil recovery and associated $\mathrm{CO}_{2}$ storage; and

(v) monitoring the performance of the reservoir during and after $\mathrm{CO}_{2}$ injection, including changes in geochemistry and geomechanical properties, the integrity of the wellbore, and any induced seismicity.

The pilot projects would also be expected to provide a wealth of data, the analysis of which could be used to establish protocols for data acquisition and interpretation during full-scale commercial deployment at a later stage. The pilot studies are expected to take around 5 years to be completed.

The Government of Indonesia and Pertamina currently favor the Sukowati project and are looking to secure financing. ADB envisages that this and possible other pilot projects, if successful, will pave the way for demonstration projects, possibly at the same field and/or others, involving the injection of much larger quantities of $\mathrm{CO}_{2}$-of the order of 500-1,000 tons per day-into a number of wells over at least 10 years. It is hoped that these projects would confirm the technical and economic feasibility of $\mathrm{CO}_{2}-\mathrm{EOR}+$ in each case, leading to the financing and large-scale rollout of the technology on a commercial basis, involving the injection of at least 2,500 tons per day over 20 years or more and the storage of a significant share of Indonesia's total $\mathrm{CO}_{2}$ emissions.

A number of issues still need to be resolved for the Sukowati project to proceed. At the field scale, there is a need for further assessment of how the faults within the reservoir will affect well communication, production rates, and carbon storage. Updates to simulation studies are also needed to predict reservoir performance, as well as a plan to monitor flow rates and the exact amount of $\mathrm{CO}_{2}$ being stored. Additional work is also required to evaluate $\mathrm{CO}_{2}$ purification and injection costs, as well as subsurface behavior of the injected $\mathrm{CO}_{2}$, wellbore integrity, and communication between the pilot wells. The current timeline envisages that the pilot would start in 2023 and, if successful, the full field-scale project in 2027.

More broadly, more work should be conducted to improve the rule-of-thumb estimates of additional oil that could be recovered from other fields with $\mathrm{CO}_{2}$-EOR using simplified reservoir models (Kuuskraa, Leewen, and Wallace, 2011), as well as more detailed assessments of the technical and economic feasibility of other projects. This would provide detailed information about the history of oil recovery and the potential $\mathrm{CO}_{2}$ storage capacity for each field of interest. These assessments would need to include a pipeline routing study to identify the best sources of $\mathrm{CO}_{2}$ for each candidate field. 
The development of pilot and demonstration projects may need to explore potential funding from the multinational institutions and the possibility of obtaining carbon emission reduction credits. The funding for these projects and possibly full-scale commercial projects is likely to come from international financing institutions such as ADB.

\section{B. Addressing Regulatory Barriers}

Since $\mathrm{CO}_{2}-\mathrm{EOR}+$ is a new activity in Indonesia, it requires the implementation of a comprehensive legal and regulatory framework covering all activities related specifically to its use. It will need to be in place by the time a commercial-scale CCS project is ready for deployment (ADB, 2013). Work on developing a general framework has been undertaken in parallel with the identification of pilot and demonstration projects with assistance from ADB. ${ }^{23}$ This has resulted in the preparation of a draft presidential decree, which was completed in March 2019-the first regulation specifically covering CCS of any developing country. ${ }^{24}$ The framework, which builds on existing regulations governing the upstream sector and industrial activities, incorporates permitting requirements and, in its current form, covers all aspects of $\mathrm{CO}_{2}-\mathrm{EOR}+$ projects, including $\mathrm{CO}_{2}$ capture from different types of sources; transportation via road, pipelines, and rail; the reception of the $\mathrm{CO}_{2}$ at the oilfield; its injection into the field; and measurement, reporting, and verification (MRV) of $\mathrm{CO}_{2}$ storage. The decree is intended to cover pilot and full commercial CCS projects and to be sufficiently detailed to give confidence to potential investors looking to pursue $\mathrm{CO}_{2}$-EOR+ projects. The development of a more comprehensive regulatory framework at a later stage is expected to benefit from the lessons learned from the pilot projects.

The primary objective of the decree is to establish a performance-based system of permitting for the storage of $\mathrm{CO}_{2}$. It sets out the standards by which CCS projects shall be permitted with the objective of mitigating the risks associated with such projects. A thorough understanding of legal and regulatory requirements to obtain permits is critical to the success of upstream projects of all types (Government of the United States, Department of Energy, 2017). The decree also provides mechanisms for coordinating the permitting process and CCS policy making more generally among government regulators, including the establishment of an interagency coordinating committee to ensure that regulatory actions are coordinated and information is shared among agencies. The decree also provides for the creation of a mechanism for public engagement at an early stage of project development to ensure a role for the public in decision-making so that local concerns are taken into consideration; to make efficient use of natural, monetary, and human resources; to promote community

${ }^{23}$ The draft decree was drawn up by a committee hosted by MEMRI in partnership with the Ministry of Environment and Forestry over July to December 2018. The directorate general of Oil and Gas, the directorate of Climate Change Mitigation in the Ministry of Environment and Forestry, the Special Work Unit for Upstream Oil and Gas Activities of SKK MIGA, the National Standardization Agency of Indonesia, LEMIGAS, Pertamina, and other government agencies also participated in committee meetings and reviewing drafts.

${ }^{24}$ CCS regulations have been adopted in Australia, Canada, and the US, while a framework regulation has been introduced in the European Union. Regulations are under consideration in the PRC and Mexico. 
development and employment opportunities; and to safeguard health, safety, the environment, and other resources.

Under the proposed framework, a CCS permit would last the entire life of the injection project, covering all injection wells. The decree sets out the application process including requirements for providing detailed information to the lead regulator to be shared with the interagency committee. The specific technology to be used would be left to the discretion of the permit applicant, though regulators may grant a permit on specific conditions to ensure that the project operates in a manner compliant with health, safety, and environmental regulations. The information requirements for permit applications, which were based on permitting regimes in Australia, the European Union, and the US, are mandatory unless the applicant can justify why the information should not be required. Information requirements fall into the following categories:

(i) technical and financial qualifications of the applicant,

(ii) geological assessment data and modeling,

(iii) project design and construction information,

(iv) monitoring and emergency remediation response plans,

(v) a mechanical well-integrity testing plan,

(vi) an operating plan,

(vii) a post-injection monitoring plan,

(viii) a closure plan, and

(ix) a seismic monitoring and risk mitigation plan.

The draft decree requires that all injection wells and other infrastructure are built using materials compatible with the injection of $\mathrm{CO}_{2}$ to ensure the integrity of injection wells, pipelines, and equipment that can be damaged due to corrosion when $\mathrm{CO}_{2}$ mixes with water or water vapor. Mechanical integrity tests are required to be completed and approved before injection can start and each year thereafter. The responsible minister may, at any time, undertake or require a CCS operator to take corrective measures to rectify significant irregularities, close leakages to stop or prevent the release of $\mathrm{CO}_{2}$, or protect human health or property. The applicant must also carry out comprehensive analysis of the potential impact of earthquakes on the storage complex and surface facilities using empirical data and modeling. Regulators can deny an application for a CCS project permit if they judge that the project poses a significant risk to health, safety, the environment, or other resources, such as mineral and water resources. In making its decision, the regulator shall consider the safety and integrity of the site in the short and long term, including an assessment of the risk of leakage of $\mathrm{CO}_{2}$ under the proposed conditions of use and of the worst-case environmental and health impacts.

The default period for monitoring under CCS permits once injection has ceased is 3 years for injection volumes of between 150,000 and 1,000,000 tons, and 10 years for over 1,000,000 tons. These periods are default periods only and can be shortened or lengthened by the regulator according to its assessment of the need for monitoring to ensure the safe operation of the injection site. Closure of the injection site occurs in three circumstances: (i) if the relevant conditions stated in the permit have been met; (ii) at the substantiated request of the operator, after authorization of the relevant minister; or (iii) if the minister so decides after the revocation of a 
CCS project permit. In the first two cases, the operator is responsible for sealing the storage site and removing injection facilities, as well as monitoring, reporting, and implementing any necessary corrective measures as required by its permit. In the latter case, the minister shall arrange monitoring and corrective measures.

The draft decree provides for operators of CCS projects, including pilots, to report various types of data to government regulators throughout the duration of the project, from the initial application to well closure at the time injection ceases and during the post-injection monitoring period. The results of the pilot projects should be used to assess the need to modify the regulations governing permitting future commercial projects (ADB, 2013).

The decree exempts pilot projects involving small-scale injections of $\mathrm{CO}_{2}$ of 150,000 tons or less from certain requirements. Other jurisdictions that have specific CCS regulations, including Australia, the European Union, and the US, have similarly exempted pilot CCS projects from full regulatory requirements to encourage investors. In particular, there is no requirement for post-injection monitoring of the $\mathrm{CO}_{2}$ plume once injection has ceased as the small volumes involved would normally present little risk to health, safety, or the environment. Other types of post-injection monitoring such as the impact of seismic activity may still be required at the discretion of the regulator. A pilot project permit may also be exempted on a case-bycase basis from complying with long-term liability provisions requiring insurance or establishing a fund for any future costs associated with maintaining an injection well after injection has ceased.

There may be a need to draw up more detailed regulations concerning specific aspects of $\mathrm{CO}_{2}$-EOR at a later stage to build on practical experience in Indonesia. These regulations need to be defined clearly as they have a significant impact on the evaluation of technical and economic risk by project developers (ITB and LEMIGAS, 2017). In preparation for large-scale deployment of the technology, it will be important for oilfield operators to start evaluating and mitigating this risk at an early stage. For example, a systematic well integrity assessment-an assessment of the risk of gas and fluids escaping in an uncontrolled manner from the wellbore-could be performed at fields where EOR is most likely to be feasible. In many cases, such risks can be minimized through minor remediation work during routine workovers. Regulatory requirements for well plugging during the abandonment phase can be reviewed and updated, if necessary. Other technical and safety risks associated with $\mathrm{CO}_{2}$-EOR projects include the migration of the injected $\mathrm{CO}_{2}$ into unintended areas and a lower rate of $\mathrm{CO}_{2}$ retention than expected. The absence of detailed regulations concerning these risks will make risk assessments carried out by project developers less comprehensive and more complicated. ${ }^{25}$ The results of risk assessments will, in turn, be of value in drawing up and refining regulations as the deployment of $\mathrm{CO}_{2}-\mathrm{EOR}+$ progresses.

25 Risk assessments that currently exist for major $\mathrm{CO}_{2}-\mathrm{EOR}+$ projects in other parts of the world can provide the basis for designing appropriate assessments in Indonesia. Pilot projects will be instrumental in providing information about region-specific risks that might have to be included in future assessments. 


\section{Financial Incentives}

There is also a need to review and recommend specific policies and tax incentives for $\mathrm{CO}_{2}-\mathrm{EOR}+$ in Indonesia. For large-scale commercial projects to take off in the country in the medium to long term, a significant financial incentive will undoubtedly be necessary, especially if oil prices fall. If there is no economic case for $\mathrm{CO}_{2}$-EOR, then there will certainly be even less of a case for $\mathrm{CO}_{2}-\mathrm{EOR}+$ unless incentives effectively lower the price of the $\mathrm{CO}_{2}$ delivered to an oilfield for injection. Demonstrating the technical feasibility of $\mathrm{CO}_{2}-\mathrm{EOR}+$ will count for little unless the technology proves to be financially attractive to upstream operators. In principle, incentives are justified by the emissions savings that investment in $\mathrm{CO}_{2}-\mathrm{EOR}+$ could achieve. The size of those incentives should take account of the marginal cost of emissions reductions in the rest of the Indonesian economy.

Incentives could take the form of a carbon tax credit, such as the $45 \mathrm{Q}$ tax credit mechanism recently adopted in the US (Box 5), or an emissions trading scheme, such as that being introduced in the PRC. Both approaches seek to place a price on carbon emissions, encouraging their use in industrial processes and their eventual storage. Implementation of such policies at an early date would provide clarity for potential investors. The framework should also take account of the "new market mechanism"26 under the Paris Agreement, which is due to come into force from 2020, and any other bi- or multilateral mechanisms that provide credits for $\mathrm{CO}_{2}$ stored in the ground.

\section{Box 5: The United States 45Q Tax Credit Mechanism for Carbon Capture, Utilization, and Storage}

This tax credit, named after the relevant section of the United States (US) tax code, aims to incentivize investment in carbon capture, utilization, and storage (CCUS) by providing credits to the entity capturing carbon dioxide $\left(\mathrm{CO}_{2}\right)$ once the gas is proven to be permanently stored. When the $\mathrm{CO}_{2}$ is captured, the facility can choose to store it in deep saline reservoirs or sell it for commercial purposes, including enhanced oil recovery (EOR). Credits vary depending on the use of the $\mathrm{CO}_{2}$. Following an amendment to the credit in 2018, the current value for deep saline storage was raised to $\$ 50$ per ton of $\mathrm{CO}_{2}$, while that for commercial sale and/or use and EOR was increased to $\$ 35$ per ton. The credits are slated to last for 12 years for projects started within a specified time period; to be eligible for the credit, a new $\mathrm{CO}_{2}$-EOR+ project would need to begin construction by 1 January 2024 . The value of these credits will be adjusted over time to take account of inflation.

Source: Authors.

\footnotetext{
${ }^{26}$ The "new market mechanism" is intended to supersede project-based emissions reduction market mechanisms, such as the Clean Development Mechanism, by counting sector- or industry-wide emissions reductions.
} 
$\mathrm{CO}_{2}$-EOR+ projects demonstrating storage of anthropogenic $\mathrm{CO}_{2}$ may also be eligible for carbon credits in the form of offset credits for emission reductions. While the same monitoring and modeling technologies apply to $\mathrm{CO}_{2}$-EOR and other types of geological storage, operators of the former will need to make additional investment in MRV to characterize, manage, and ensure the long-term integrity of storage, as well as optimal EOR operations (as described in Section II). MRV requirements for both the operation and shutting-in of $\mathrm{CO}_{2}-\mathrm{EOR}+$ projects at the end of the field's life will be crucial for such projects to qualify for carbon credits. Monitoring protocols have been developed by groups such as the American Carbon Registry (American Carbon Registry, 2015) and are also under development through the International Standards Organization. These standards could be adopted by Indonesia with modifications to take account of local factors.

\section{Developing In-Country Capability}

The development of human capital will be an important element in achieving the successful demonstration and subsequent large-scale deployment of $\mathrm{CO}_{2}-\mathrm{EOR}+$ technology in Indonesia. In particular, learning and knowledge must be transferred from $\mathrm{CO}_{2}-\mathrm{EOR}+$ projects in other parts of the world. Capacity building among local stakeholders must occur across all aspects of project development: technical, financial, environmental, community engagement, regulatory, legal, and institutional (ADB, 2013). To this end, the partnership between ITB and LEMIGAS through the CoE for CCS and/or CCUS, the existing collaboration between LEMIGAS and Pertamina, and the help of experts assisting ADB are good examples of ways of building in-house capability. These should be continued and enhanced. The pilot projects would also facilitate building the expertise in planning, construction, operation, and completion of $\mathrm{CO}_{2}$-EOR+ projects. The presence and involvement of local personnel throughout the project development cycle would also facilitate capacity building and minimize the need for international technical assistance by the time demonstration projects are deployed (ADB, 2013). 



\section{REFERENCES}

M. Abdurrahman, A. Permadi, W. Bae, and A. Masduki. 2017. EOR in Indonesia: Past, Present, and Future. International Journal of Oil and Gas Technology. 16 (3). pp. 250-270. Geneva and New York: Inderscience Publishing. https://www.researchgate. net/publication/319365676_EOR_in_Indonesia_Past_present_and_future.

American Carbon Registry. 2015. Methodology for Greenhouse Gas Emission Reductions from Carbon Capture and Storage Projects. Version 1.0. Little Rock, Arkansas: Winrock International. https://americancarbonregistry.org/carbon-accounting/standardsmethodologies/carbon-capture-and-storage-in-oil-and-gas-reservoirs/acr-ccsmethodology-v1-0-final.pdf.

Asian Development Bank (ADB). 2013. Prospects for Carbon Capture and Storage in Southeast Asia. Manila. https://www.adb.org/publications/prospects-carbon-captureand-storage-southeast-asia.

ADB. Indonesia: Pilot Carbon Capture and Storage Activity in the Natural Gas Processing Sector (TA 9189-INO). https://www.adb.org/projects/49204-002/main.

N. Azzolina, W. Peck, J. Hamling, C. Gorecki, S. Ayash, T. Doll, and L. Melzer. 2016. How Green is My Oil? A Detailed Look at Greenhouse Gas Accounting for $\mathrm{CO}_{2}$-Enhanced Oil Recovery ( $\mathrm{CO}_{2}$-EOR) Sites. International Journal of Greenhouse Gas Control. 51. pp. 369-379. https://www.sciencedirect.com/science/article/pii/S1750583616302985.

N. Azzolina, D. Nakles, C. Gorecki, W. Peck, S. Ayash, L. Melzer, and S. Chatterjee. 2015. $\mathrm{CO}_{2}$ Storage associated with $\mathrm{CO}_{2}$-Enhanced Oil Recovery: A Statistical Analysis of Historical Operations. International Journal of Greenhouse Gas Control. 37. pp. 384397. https://www.sciencedirect.com/science/article/abs/pii/S1750583615001413.

Badan Pengkajian dan Penerapan Teknologi (Agency for the Assessment and Application of Technology). 2018. Indonesia Energy Outlook 2018: Sustainable Energy for Land Transportation. Jakarta. https://d1io3yog0oux5.cloudfront.net/_ ade37ec3f94db1428dc189f527dac2fb/continentalenergy/db/337/2200/pdf/BPPT+O utlook+Energi+Indonesia+2018.

Battelle analysis based on Muslim et al. 2013. Opportunities and Challenges of $\mathrm{CO}_{2}$ Flooding in Indonesia. Paper presented at the Society of Petroleum Engineers Asia Pacific Oil and Gas Conference and Exhibition. Jakarta. 23-24 October. https://www.academia. edu/10778808/Opportunities_and_Challenges_of_CO2-EOR_in_Indonesia. 
Carbon Sequestration Leadership Forum. 2019. Uthmaniyah Carbon Dioxide Enhanced Oil Recovery $\left(\mathrm{CO}_{2}\right.$-EOR) Demonstration Project. https://www. cslforum.org/cslf/Projects/Uthmaniyah.

G. Cooney, J. Littlefield, J. Marriott, and T. Skone. 2015. Evaluating the Climate Benefits of $\mathrm{CO}_{2}$-Enhanced Oil Recovery Using Life Cycle Analysis. Environmental Science and Technology. 49 (12). pp. 7491-7500. https://pubs.acs. org/doi/ipdf/10.1021/acs.est.5b00700.

Global CCS Institute. CCS Image Library - Carbon Capture and Storage Images. https://www.globalccsinstitute.com/resources/ccs-image-library/.

Global CCS Institute. 2018. Global Status of CCS 2018. Melbourne. https://www. globalccsinstitute.com/resources/global-status-report/download/.

Government of Indonesia, Ministry of Energy and Mineral Resources of the Republic of Indonesia (MEMRI). 2018a. Current Status and Future Path of Developments for CCUS in Indonesia. Jakarta: LEMIGAS Research and Development for Oil and Gas. 8 June. https://d2oc0ihd6a5bt.cloudfront.net/wp-content/uploads/ sites/837/2018/06/Usman-Pasarai-Current-Status-and-Future-Path-ofDevelopments-for-CCUS-in-Indonesia.pdf.

Government of Indonesia, MEMRI. 2018b. Handbook of Energy \& Economic Statistics of Indonesia. Final Edition. Jakarta. https://www.esdm.go.id/assets/media/content/ content-handbook-of-energy-and-economic-statistics-of-indonesia-2018final-edition.pdf.

Government of Indonesia, Ministry of Finance. 2015. Fiscal Policy Options for Promoting Carbon Capture and Storage in the Oil and Gas Industries in Indonesia. Final Discussion Paper for the Low Carbon Support Program. Jakarta.

Government of Indonesia, MEMRI. 2014. Indonesia Energy Policy. Jakarta. https:// eneken.ieej.or.jp/data/5587.pdf.

Government of Indonesia. n.d. New Paradigm of Indonesia Energy Policy and Planning. Jakarta: Indonesia National Energy Council. https://www.doe.gov.ph/sites/ default/files/pdf/announcements/acd_14_new_paradigm_indonesia_energy_ policy_and_planning.pdf.

Government of the United States, Department of Energy. 2019. Enhanced Oil Recovery. Washington, DC: Office of Fossil Energy. https://www.energy.gov/fe/ science-innovation/oil-gas-research/enhanced-oil-recovery.

Government of the United States, Office of the Law Revision Counsel. 2019. 26 USC 45Q: Credit for Carbon Oxide Sequestration. Washington, DC: United States Code. 3 October. http://uscode.house.gov/view.xhtml?req=\%28title:26\%20 section:45Q\%20edition:prelim\%29 (accessed 14 October 2019). 
Government of the United States, Department of Energy. 2017. Best Practices for Monitoring, Verification, and Accounting for Geologic Storage Projects. Pittsburgh: National Energy Technology Laboratory.

Government of the United States, Environmental Protection Agency. 2015. Memorandum to the Regional Water Division Directors regarding the Key Principles in EPA's Underground Injection Control Program Class VI Rule Related to Transition of Class II Enhanced Oil or Gas Recovery Wells to Class VI. Washington, DC. Office of Ground Water and Drinking Water. 23 April. https://www.epa.gov/sites/production/files/2015-07/documents/ class2eorclass6memo_1.pdf.

N. Gupta, L. Cumming, J. Sminchak, A. Pasumarti, and P. Rvai. 2016. United Mexican States MX TF Carbon Capture, Utilization and Storage Development in Mexico: Combining $\mathrm{CO}_{2}$ Enhanced Oil Recovery with Permanent Storage in Mexico. Final Report-Review of Current Status and Identification of Key Issues. Washington, DC: World Bank. https://www.gob.mx/cms/uploads/attachment/file/107317/ CO2EOR-CCS_Final_Report.pdf.

A. Haagsma, S. Weber, M. Moody, and N. Gupta. 2016. Comparative Wellbore Integrity Evaluation across a Complex of Oil and Gas Fields within the Michigan Basin and Implications for $\mathrm{CO}_{2}$ Storage: Modelling and Analysis. Greenhouse Gases: Science and Technology. 7(5).

L. B. Hill, S. Hovorka, and S. Melzer. 2013. Geologic Carbon Storage through Enhanced Oil Recovery. Energy Procedia. 37. pp. 6808-6830.

B. Hitchon, ed. 2012. Best Practices for Validating $\mathrm{CO}_{2}$ Geological Storage: Observations and Guidance from the IEA GHG Weyburn-Midale $\mathrm{CO}_{2}$ Monitoring Project. Sherwood Park: Geoscience Publishing.

Indonesia CCS Working Group. 2009. Understanding Carbon Capture and Storage Potential in Indonesia. Joint Cooperation between the United Kingdom CCS Research Centre and the Government of Indonesia on Strategic Programme Fund. Jakarta. https://ukccsrc.ac.uk/publication_ccs_repo/understandingcarbon-capture-and-storage-potential-in-indonesia/.

International Energy Agency. Carbon Capture, Utilisation and Storage. https://www. iea.org/topics/carbon-capture-and-storage/.

International Energy Agency. 2018a. World Energy Outlook 2018. Paris: Organisation for Economic Co-operation and Development / IEA.

International Energy Agency. 2018b. World Energy Investment 2018. Paris: Organisation for Economic Co-operation and Development / IEA.

International Energy Agency. 2018c. World Energy Outlook 2018 - EOR Database. https://www.iea.org/media/publications/weo/EOR-database-WEO18.xlsx (accessed 14 October 2019). 
International Energy Agency. 2017. $\mathrm{CO}_{2}$ Emissions from Fuel Combustion. Paris: Organisation for Economic Co-operation and Development / IEA.

International Energy Agency. 2015. Storing $\mathrm{CO}_{2}$ through Enhanced Oil Recovery: Combining EOR with $\mathrm{CO}_{2}$ Storage $(E O R+)$ for Profit. Paris: Organisation for Economic Co-operation and Development / IEA.

International Energy Agency. 2014. CCS 2014: What Lies in Store for CCS? Paris: Organisation for Economic Co-operation and Development / IEA.

International Energy Agency. 2013. Resources to Reserves. Paris: Organisation for Economic Co-operation and Development / IEA.

International Energy Agency. 2009. World Energy Outlook 2009. Paris: Organisation for Economic Co-operation and Development / IEA.

International Energy Agency. Total Primary Energy Supply (TPES) by Source, Indonesia 1990-2017. IEA Statistics. https://www.iea.org/statistics/ (accessed 14 October 2019).

Institut Teknologi Bandung (ITB or Bandung Institute of Technology) and LEMIGAS. 2017. Knowledge Partnership Program: Promoting Carbon Capture and Storage in Indonesia. Jakarta: ITB/LEMIGAS.

G. Kristopher. 2015. Why it's Important to Know the Crude Oil Extraction Process. Market Realist. 15 January. https://marketrealist.com/2015/01/important-knowcrude-oil-extraction-process/.

V. Kuuskraa, T. Leewen, and M. Wallace. 2011. Improving Domestic Energy Security and Lowering $\mathrm{CO}_{2}$ Emissions with 'Next Generation' $\mathrm{CO}_{2}$-Enhanced Oil Recovery ( $\left.\mathrm{CO}_{2}-E O R\right)$. Pittsburgh: US Department of Energy Office of Fossil Energy/ National Energy Technology Laboratory. https://www.osti.gov/biblio/1503260improving-domestic-energy-security-lowering-CO2-emissions-nextgeneration-CO2-enhanced-oil-recovery.

LEMIGAS. 2018. The Latest Status of CCS in Indonesia. Jakarta. http://www.ccop.or.th/ ccsm/data/7/docs/Indonesia_LEMIGAS.pdf.

LEMIGAS. 2017. Knowledge Partnership Program: Promoting Carbon Capture and Storage in Indonesia. Jakarta.

LEMIGAS. 2009. Understanding Carbon Capture and Storage Potential in Indonesia. Jakarta. https://ukccsrc.ac.uk/system/files/publications/ccs-reports/DECC_ CCS_117.pdf.

A. Manuilova, J. Koiwanit, L. Piewkhaow, M. Wilson, C. Chan, and P. Tontiwachwuthikul. 2014. Life Cycle Assessment of Post-Combustion $\mathrm{CO}_{2}$ Capture and $\mathrm{CO}_{2}$-Enhanced Oil Recovery based on Boundary Dam Integrated 
Carbon Capture and Storage Demonstration Project in Saskatchewan. Energy Procedia. 63. pp. 7398-7407.

C. McGlade, G. Sondak, and M. Han. 2018. Commentary: Whatever Happened to Enhanced Oil Recovery? IEA Newsroom. 28 November. https://www.iea.org/ newsroom/news/2018/november/whatever-happened-to-enhanced-oilrecovery.html.

L. S. Melzer. 2012 Carbon Dioxide Enhanced Oil Recovery ( $\mathrm{CO}_{2}$-EOR): Factors Involved in Adding Carbon Capture, Utilization and Storage (CCUS) to Enhanced Oil Recovery. Paper presented at the $\mathrm{CO}_{2}$-EOR and Geologic Sequestration Workshop. Stanford University. February. https://carboncapturecoalition.org/ wp-content/uploads/2018/01/Melzer_CO_EOR_CCUS_Feb2012.pdf.

W. Muslim, A. Permadi, B. Gunadi, D. Saputra, R. Widyaningsih, and T. Gundi. 2013. Opportunities and Challenges of $\mathrm{CO}_{2}$ Flooding in Indonesia. Paper presented at the Society of Petroleum Engineers Asia Pacific Oil and Gas Conference and Exhibition. Jakarta. 23-24 October. https://www.academia.edu/10778808/ Opportunities_and_Challenges_of_CO2-EOR_in_Indonesia.

NRG Energy, Inc. Petra Nova: Carbon Capture and the Future of Coal Power. https:// www.nrg.com/case-studies/petra-nova.html.

Pertamina. 2018. Carbon Dioxide-Enhanced Oil Recovery Project at Sukowati Field. Presentation slides during the Asian Development Bank; Center of Excellence (CoE) for Carbon Capture and Storage (CCS) and Carbon Capture, Utilization, and Storage (CCUS); LEMIGAS; and CoE Institut Teknologi Bandung (ITB, Bandung Institute of Technology) Sukowati CCUS Enhancement First Review Meeting. Jakarta. 4 December.

Petroleum Technology Research Centre. Weyburn-Midale: The IEA GHG WeyburnMidale $\mathrm{CO}_{2}$ Monitoring and Storage Project. https://ptrc.ca/projects/pastprojects/weyburn-midale.

E. Putra. 2016. Evaluation of $\mathrm{CO}_{2}-\mathrm{EOR}$ Injection and Its Potential Application to Indonesia. Houston: Enerproco. http://siephouston.org/wp-content/ uploads/2017/06/CO2-EOR-SIEPH-Putra.pdf.

PwC. 2017. Power in Indonesia: Investment and Taxation Guide. Fifth Edition. Jakarta. https://www.pwc.com/id/en/energy-utilities-mining/assets/power/powerguide-2017.pdf.

PwC. 2018. Oil and Gas in Indonesia: Investment and Taxation Guide. Ninth Edition. Jakarta. https://www.pwc.com/id/en/energy-utilities-mining/assets/oil-and-gas/ oil-and-gas-guide-2018.pdf. 
D. Rukmana. 2017. Potensi $\mathrm{CO}_{2}$ CCUS-EOR Di Indonesia (Potential for $\mathrm{CO}_{2}-\mathrm{EOR}$ in Indonesia). Jakarta: SKK Migas (Special Task Force for Upstream Oil and Gas Business Activities) (in Indonesian).

U. Siagian, R. Dewi, R. Boer, I. Hendrawan, B. Yuwono, and G. Ginting. 2015. Pathways to Deep Decarbonization in Indonesia. New York: Sustainable Development Solutions Network (SDSN) and Institute for Sustainable Development and International Relations (IDDRI).

United Nations Framework Convention on Climate Change. 2016. First Nationally Determined Contribution: Republic of Indonesia. November. https://www4. unfccc.int/sites/ndcstaging/PublishedDocuments/Indonesia\%20First/First $\% 20$ NDC\%20Indonesia_submitted\%20to\%20UNFCCC\%20Set_November\%20 \%202016.pdf.

C. Ward, W. Heidug, and N. Bjurstrom. 2018. Enhanced Oil Recovery and $\mathrm{CO}_{2}$ Storage Potential Outside North America: An Economic Assessment. Riyadh: King Abdullah Petroleum Studies and Research Center.

A. Wijaya, H. Chrysolite, M. Ge, C. K. Wibowo, A. Pradana, A. F. Utami, and K. Austen. 2017. How Can Indonesia Achieve Its Climate Change Mitigation Goal? An Analysis of Potential Emissions Reductions from Energy and Land-Use Policies. Working Paper. September. Washington, DC: World Resources Institute. 


\section{Carbon Dioxide-Enhanced Oil Recovery in Indonesia An Assessment of its Role in a Carbon Capture and Storage Pathway}

This publication assesses the potential of carbon dioxide-enhanced oil recovery $\left(\mathrm{CO}_{2}\right.$-EOR) technology to mitigate climate change in Indonesia. Although the technology was designed to rejuvenate oil production in mature oilfields, its value in permanently storing $\mathrm{CO}_{2}$ has recently attracted global interest. The publication concludes that $\mathrm{CO}_{2}$-EOR could provide a win-win for Indonesia by improving oil production while also helping to reduce the country's rapidly rising greenhouse gas emissions. It proposes a pilot project as a critical first step to deploy the technology and provides insights on how to create a supportive regulatory environment and financial incentives.

\section{About the Asian Development Bank}

ADB is committed to achieving a prosperous, inclusive, resilient, and sustainable Asia and the Pacific, while sustaining its efforts to eradicate extreme poverty. Established in 1966, it is owned by 68 members -49 from the region. Its main instruments for helping its developing member countries are policy dialogue, loans, equity investments, guarantees, grants, and technical assistance. 